NBER WORKING PAPER SERIES

\title{
TRENDS IN HOURS, BALANCED GROWTH, AND THE ROLE OF TECHNOLOGY IN THE BUSINESS CYCLE
}

\author{
Jordi Galí \\ Working Paper 11130 \\ http://www.nber.org/papers/w11130 \\ NATIONAL BUREAU OF ECONOMIC RESEARCH \\ 1050 Massachusetts Avenue \\ Cambridge, MA 02138 \\ February 2005
}

Prepared for the 29th Economic Policy Conference on .Productivity, Labor and the Business Cycle,. organized by the Federal Reverve Bank of St. Louis, October 20-21, 2004. The author thanks Chris Sims for useful comments, and Anton Nakov for excellent research assistance. The views expressed herein are those of the author(s) and do not necessarily reflect the views of the National Bureau of Economic Research.

(C) 2005 by Jordi Galí. All rights reserved. Short sections of text, not to exceed two paragraphs, may be quoted without explicit permission provided that full credit, including $(\odot)$ notice, is given to the source. 
Why Have Housing Prices Gone Up?

Jordi Galí

NBER Working Paper No. 11130

February 2005

JEL No. E32

\begin{abstract}
The present paper revisits a property embedded in most dynamic macroeconomic models: the stationarity of hours worked. First, I argue that, contrary to what is often believed, there are many reasons why hours could be nonstationary in those models, while preserving the property of balanced growth. Second, I show that the postwar evidence for most industrialized economies is clearly at odds with the assumption of stationary hours per capita. Third, I examine the implications of that evidence for the role of technology as a source of economic fluctuations in the G7 countries.

\author{
Jordi Galí \\ Centre de Recerca en Economia Internacional (CREI) \\ Ramon Trias Fargas 25 \\ 08005 Barcelona SPAIN \\ and NBER \\ jordi.gali@upf.edu
}




\section{Introduction}

Business cycles have long been associated with highly procyclical fluctuations in labor input measures. In the mind of the common man, the recurrent ups and downs in employment (or unemployment) observed in modern economies are arguably more of a defining feature of the business cycle than the accompanying fluctuations in GDP. ${ }^{1}$ Understanding the factors underlying the joint variation of output and labor input measures remains a key item in macroeconomists' research agenda.

The present paper focuses on a dimension of those joint fluctuations that is generally ignored by macroeconomists, in theoretical as well as in empirical analysis: the long run behavior of hours worked. In particular, the paper revisits a property common to the majority of intertemporal equilibrium models used in macroeconomic applications, namely, that of stationarity of hours worked per capita. First, I argue that, contrary to what is often believed, stationarity of (per capita) hours is not a necessary condition in order for those models to generate a balanced growth path. Second, and perhaps most importantly, I show that the evidence for the G7 economies is generally at odds with the key equilibrium relationship that underlies the stationarity of hours in those models. In fact, that evidence suggests that both margins of labor utilization (i.e., hours per worker and the employment rate) display some nonstationarity features in most G7 countries.

The evidence of nonstationarity in hours per worker points to the importance of using an hours-based measure of productivity when estimating the effects of technology shocks under the approach proposed in Galí (1999), in which technology shocks are identified as the only source of non-stationarity in labor

\footnotetext{
${ }^{1}$ Notice also that employment is one of the four monthly indicators monitored by the NBER Business Cycle Committee for the dating of recessions.
} 
productivity. The reason is straightforward: shocks unrelated to technology that have a permanent effect on hours per worker (but not on output per hour) would be a source of nonstationarity in employment-based measures of productivity, and would thus be mislabeled as technology shocks. Below I revisit the international evidence on the effects of technology shocks using an hours-based measure of productivity, finding little evidence in support of a major role of technology as a source of business cycles.

The paper is organized as follows. Section 2 discusses the relationship between the stationarity of hours and the balanced growth hypothesis. Section 3 provides some evidence on the behavior of the two margins of labor utilization for the G7 countries, and discusses the implications of that evidence. Section 4 presents new estimates of the effects and role of technology shocks in the G7 countries. Section 5 concludes.

\section{The Stationarity of Hours and the Balanced Growth Hypothesis}

Since the seminal work by Kydland and Prescott (1982) and Prescott (1986), most business cycle models have adopted a neoclassical growth framework (augmented with a consumption-leisure choice) as a "core structure," on which stochastic disturbances and frictions of different sorts are added. The choice of a specification for preferences and technology in the resulting models has been generally guided by the requirement that the underlying deterministic model is consistent with some "stylized facts" of growth. It is generally argued that imposing such a requirement facilitates calibration of the model on the basis of information unrelated to the business cycle phenomena that the model seeks to explain.

Prominent among those stylized facts is the observation that many key 
macroeconomic variables like output, consumption, investment, and the stock of physical capital display a similar average rate of growth over sufficiently long periods of time. That property is referred to as "balanced growth". Another important observation is that hours worked per capita do not display any obvious trend that one could associate with the secular upward trend shown by the real wage. Third, and in contrast to the real wage, the return to capital (as reflected, say, in the real interest rate) does not seem to display any significant long run trend.

The analysis of King et al. (1988), among others, pointed out that the predictions of the neoclassical framework can be reconciled with the previous facts if (i) technology can be represented by a constant returns production function with labor-augmenting technical progress, (ii) preferences display a constant elasticity of intertemporal substitution, and (iii) the marginal rate of substitution between consumption and hours (or leisure) is homogeneous of degree one in consumption. Specifications satisfying those properties are commonly adopted "as a discipline device" by business cycle theorists, even when their subject of inquiry is viewed as being unrelated to the forces underlying long term growth.

Unfortunately, and as argued below, the widespread adoption of an unnecessarily strong version of the balanced growth hypothesis has led to a common misconception, namely, that stationarity of hours worked is an inherent feature of models displaying balanced growth. ${ }^{2}$

\footnotetext{
${ }^{2}$ Cooley and Prescott (1995), among others, provide an explicit account of that strategy: "...we are going to restrict our attention to artificial economies that display balanced growth. In balanced growth consumption, investment, and capital all grow at a constant rate, while hours stay constant."
} 


\subsection{A Benchmark Framework with no Frictions}

To illustrate the basic point let us first assume a constant returns Cobb-Douglas technology, implying the following linear expression for the (log) marginal product of labor: ${ }^{3}$

$$
m p n_{t}=y_{t}-n_{t}
$$

where $y_{t}$ denotes output and $n_{t}$ is hours worked (or hours, for short), both normalized by the size of the working-age population and expressed in logs.

Second, and in a way consistent with the requirements derived by King et al. (1988), let us assume that preferences imply the following expression for the $(\log )$ marginal rate of substitution

$$
m r s_{t}=c_{t}+\varphi n_{t}
$$

where $c_{t}$ denotes the $\log$ of per capita consumption, and $\varphi$ is the reciprocal of the Frisch labor supply elasticity. ${ }^{4}$ Notice that normality of both consumption and leisure requires that $\varphi>0$.

In a benchmark RBC model with perfect competition in goods and labor markets and no other distortions, the efficiency condition $m r s_{t}=m p n_{t}$ holds at all times, implying

$$
n_{t}=-(1+\varphi)^{-1} s_{c, t}
$$

where $s_{c, t} \equiv c_{t}-y_{t}$ is the $\log$ of the share of consumption in output (henceforth, the "consumption share"). The intuition behind the negative relationship is simple: starting from an efficient allocation, both an increase in consumption (given output) or a decline in output (given consumption) make an additional unit of leisure more valuable than the marginal use of time in productive activities, thus calling for a drop in hours to maintain efficiency.

\footnotetext{
${ }^{3}$ Constant terms are ignored throughout the paper.

${ }^{4}$ The assumption of a constant elasticity of the marginal rate of substitution with respect to hours can be relaxed, but is adopted here for convenience.
} 
The "strong" version of the balanced growth property adopted in most macroeconomic applications requires that $s_{c, t}$ fluctuates about a constant mean value $s_{c}$. As a result, it must also be the case that hours are stationary, and fluctuate around a constant mean $n=-(1+\varphi)^{-1} s_{c}$. In the standard RBC model (closed economy, no government) the steady sate consumption share $s_{c}$ and, hence, steady state hours, are determined exclusively by preference and technology parameters.

\subsection{Hours Worked and the Consumption Share: Evidence for the United States}

Next I turn to the data, in order to provide an assessment of the relationship between hours and the consumption share displayed in (1), and implied by the simple framework exposited above.

I start by looking at aggregate quarterly U.S. data. ${ }^{5}$ I use hours of all persons in the nonfarm business sector (LXNFH), normalized by the size of the population aged 16 or older, as a benchmark measure of hours. As a benchmark series for the consumption share I use the ratio of personal consumption expenditures in nondurable goods and services $(\mathrm{CN}+\mathrm{CS})$ to gross domestic product (GDP), both expressed in current prices. ${ }^{6}$ Figure 1.A displays the empirical counterparts to $n_{t}$ and $s_{c, t}$. While some negative short-run comovement between the two series is easily discernible, it is clear that the overall picture is dominated by what looks like a common upward trend in the second half of the sample period.

Figure 1.B displays the business cycle component of the two series, obtained by applying the band-pass filter developed in Baxter and King (1999), and

\footnotetext{
${ }^{5}$ Quarterly U.S. data are drawn from from the USECON data set. The sample period is 1948:1-2003:4. The corresponding mnemonics are shown in brackets.

${ }^{6}$ In the Appendix I show that this is the right measure if one allows for changes in the relative price of consumption goods.
} 
calibrated to remove fluctuations of periodicity outside an interval between 6 and 32 quarters. Once the low frequency trends are dispensed with, a strong negative comovement between hours and the consumption share emerges clearly. That relationship is consistent with two stylized fact of business cycles, namely, the procyclicality of hours worked and the fact that consumption is less volatile than output at business cycle frequencies (which makes the consumption share countercyclical).

The previous visual assessment is confirmed by a straighforward statistical analysis. Thus, a simple OLS regression of (log) hours on the (log) consumption share yields the following estimated equation (standard errors in brackets, constant term ignored):

$$
n_{t}=\underset{(0.05)}{0.16} s_{c, t} \quad R^{2}=0.03
$$

with the simple correlation between the two variables being 0.19 . Notice that the fit of the estimated regression equation, as measured by the $R^{2}$, is extremely low for a relationship that is supposed to hold exactly. To make things worse, the sign of the estimated coefficient is inconsistent with the theory's prediction.

By way of contrast, an OLS regression using the business cycle component of both series yields the estimated equation

$$
n_{t}=\underset{(0.06)}{-1.26} s_{c, t} \quad R^{2}=0.61
$$

with the corresponding correlation being -0.78 . Thus, and while far from displaying the exact relationship implied by the benchmark model, the business cycle component of hours and the consumption share shows a very strong negative comovement. Notice also that, strictly speaking, the estimated coefficient on the consumption share with an absolute value greater than one is inconsistent with the theory (since it would imply that leisure is an inferior good). Given the lack of a structural interpretation of the error term, combined with the likely 
distortions introduced by the detrending filter, I do not want to put too much emphasis on the point estimate. ${ }^{7}$ Yet, it is worth noticing that the previous finding seems consistent with the requirement stressed by RBC theorists of a high intertemporal substitution in labor supply in order to account for the large fluctuations in hours. ${ }^{8}$

\subsubsection{Robustness: Alternative Measures}

Similar findings emerge when I use an alternative, more comprehensive, measure of aggregate hours constructed by multiplying total civilian employment (LE) by average weekly hours in manufacturing (LRMANUA). The same is true for measures of the consumption share constructed using two alternative definitions of consumption, namely, total private consumption (C)-which includes durable goods expenditures-, and total consumption (C+GFNE+GSE), which includes, in addition, nondefense government consumption.

Table 1 reports the estimates of the coefficient of an OLS regression of (log) hours on the $(\log )$ consumption share, using all possible combinations of measures of both variables, and with standard errors reported in brackets. The second column reports the corresponding correlations. The third and four columns show analogous statistics using the business cycle component of each series. Interestingly, when the (unfiltered) data are used, the regression coefficient has the wrong sign for all specifications. When I use data on total hours (see bottom panel) the correlation becomes higher and significant, but always with the wrong sign (positive). The latter just captures the fact that both series display a common upward trend for most of the period.

Again, when we turn to the business cycle component, the results change dramatically: a very strong negative comovement between hours and the con-

\footnotetext{
${ }^{7}$ A similar finding, albeit in the context of extimation of a staggered price setting model, is found in Sbordone (2000)

${ }^{8}$ As exemplified by the indivisible model of Hansen (1985) and Rogerson (1988).
} 
sumption share emerges for all the specifications.

\subsection{Hours Worked and the Consumption Share: Interna- tional Evidence}

Next I examine the comovements of hours and the consumption share for the G7 countries, in order to assess the extent to which the evidence in the previous subsection is specific to the U.S. or carries over to other countries. In doing so I use the data set on hours worked (normalized by population aged 14-65) constructed by the OECD and part of their Labor Force Statistics dataset. The data frequency is annual and the sample period, common across countries, starts in 1970 and ends in 2002. The graphs on the left hand side of Figure 2 display, for each country, the time series for hours and the share of (total) consumption in GDP. The graphs on the right hand side show the growth rates of the same variables. ${ }^{9}$ That graphical evidence is supplemented with Table 2, which reports, for each country, the correlation between the (log) consumption share and $(\log )$ hours, in both levels and first differences.

While the patterns of both variables seen in the figures display substantial differences across countries, two basic common features are apparent. First, neither the consumption share nor hours per capita display any tendency to revert to some constant mean, over the thirty year period considered. In other words, there seems to be prima facie evidence of some sort of nonstationarity in both series. Second, and as confirmed by the correlations in Table 2, there is no evidence of the tight negative relationship between those variables suggested by (1). Japan is the only country for which a strong negative correlation can be found between the $(\log )$ levels of the two variables.

As it was the case with quarterly U.S. data, when we turn our attention to

${ }^{9}$ Ggiven the annual frequency of the data, growth rates provide a better representation of short term fluctuations. 
higher frequency changes (as represented by first differences here), the correlations become negative (with the exception of Italy), but they are still rather low in absolute value, and far from the perfect correlation implied by the benchmark framework above.

\subsection{Interpretation}

Notice that even under the baseline neoclassical framework described above, one can think of plausible reasons that would render the consumption share nonstationary, and which could thus provide a potential explanation for the nonstationarity in hours within the paradigm. The presence of permanents shifts (or an underlying trend) in the share of government purchases in GDP may be the most obvious one, and one that seems to be relevant in the case of the postwar U.S. economy (since the early 50s to the late 90s that share declined by about 5 percentage points). Yet, according to the benchmark neoclassical framework, the increase in the consumption share should have come hand in hand with a reduction in hours, not an increase like the one observed in the U.S. economy-a pattern displayed also by Canada and Germany-nor with the largely disconnected long run pattern of hours displayed by other countries (with the possible exception of Japan).

More generally, modern economies are subject to a variety of frictions and distortions that can account for permanent shifts-and, thus unit-root like behaviorin hours. Furthermore, this can occur without violating the central element of the balanced growth hypothesis, namely, that over the long run the main components of aggregate demand are expected to grow at the same rate (or, in other words, their growth rates have a common unconditional expectation).

To illustrate this point consider the following extension of the framework above, along the lines of Galí, Gertler, and López-Salido (2003). First, one 
may want to allow for a possible wedge between the marginal product of labor (which, for simplicity, we keep equating to average labor productivity) and the real wage paid by the firm per hour of work. Letting $\mu_{t}^{p}$ denote that wedge we thus have (in logs):

$$
\begin{aligned}
w_{t}-p_{t} & =m p n_{t}-\mu_{t}^{p} \\
& =\left(y_{t}-n_{t}\right)-\mu_{t}^{p}
\end{aligned}
$$

Second, a wedge may exist between the wage and the (average) household's marginal rate of substitution, as a result of labor income taxes, wage setting by unions, efficiency wages, etc. ${ }^{10}$ Formally, and letting $\mu_{t}^{w}$ denote that wedge, we have

$$
w_{t}-p_{t}=m r s_{t}+\mu_{t}^{w}
$$

Finally, and as emphasized by Hall (1997), the marginal rate of substitution may experience stochastic shifts-some of which might be permanent-both as a result of genuine shifts in invidual tastes or composition effects derived from demographic forces. We can represent that feature by appending a preference shock $\xi_{t}$ to our expression for the (log) marginal rate of substitution:

$$
m r s_{t}=c_{t}+\varphi n_{t}+\xi_{t}
$$

Combining (2), (3), and (4) we obtain the following expression for hours:

$$
n_{t}=-(1+\varphi)^{-1}\left(s_{c, t}+\mu_{t}^{p}+\mu_{t}^{w}+\xi_{t}\right)
$$

Hence, we see that, any permanent shifts in the labor and product market wedges or in preferences will result in a permanent shift in hours worked, for any given consumption share. To the extent that we are willing to allow for changes

\footnotetext{
${ }^{10}$ This is the wedge emphasized in Mulligan (2002), who provides an analysis of its long-run behavior in the U.S.
} 
in any of those variables, there is no obvious reason (other than modelling convenience) why all those changes should be stationary. The presence of price and wage stickiness, with their consequent temporary deviations in markups from their desired levels, appears perhaps as the only "natural" source of stationarity in the fluctuations in hours in this context. Some changes in desired markups, on the other hand, are likely to be permanent (e.g., those resulting from changes in the regulatory environment) This is also true of changes in taxes that may affect the labor market wedge. ${ }^{11}$ Needless to say, many shifts in preferences or in the share of consumption in GDP are likely to be permanent in nature.

Given the above considerations, the apparent nonstationarity in hours and its decoupling from the consumption share should come as no surprise, despite its central role in common versions of business cycle models. ${ }^{12}$

\subsection{The Two Margins of Hours Variation: A Look at the International Evidence}

It is not the purpose of the present paper to uncover and even less so to quantify the relative importance of the different likely sources of nostationarity in hours. Yet, a look at the two margins of variation in hours, namely, hours per worker and the employment rate, suggest that a simple representative agent model will find it hard to account for the labor market dynamics behind the observed changes in hours. The low frequency changes in both margins are substantial, and display patterns that vary significantly across countries. This is illustrated in Figures 3.A-3.G, which show for each G7 country, the evolution of hours worked per capita (more precisely, per person aged 16 to 65), average hours

\footnotetext{
${ }^{11}$ Thus, Prescott (2004) argues that differences in labor income taxes can account for the gap in hours worked between the US and Europe. Mulligan (2002) provides evidence of large and persistent changes in the labor market wedge.

12 See Francis and Ramey (2003) for a similar argument using a fully specified growth model. In their model, permanent changes in government purchases, tax rates or a preference parameter are shown to have a permanent effect on steady state hours.
} 
per worker, and the employment rate (i.e., the ratio of employment to working age population). The data are drawn from the labour force statistics dataset compiled by the OECD, with the sample periods differing somewhat across countries.

As a cursory look at the figures makes clear, the evidence constitutes an embarrassment of riches. Thus, for instance, the U.S. and Canada display an upward trend in hours per capita in the late part of the sample, which is the result of a continuous increase in the employment rate, combined with a flat pattern for hours per worker. In the early part of the sample, on the other hand, the relatively stable path for hours per capita hides very different (mutually offsetting) trends in hours per worker (downward), and the employment rate (upward).

The remaining G7 countries.have experienced instead a secular decline in hours per capita. But again, the underlying composition differs across countries. Thus, in the U.K. and Italy it is largely the result of a decline in hours per worker, combined with a relatively stable employment rate. In Japan, hours per capita decline in spite of a persistent upward trend in the employment rate. In France and Germany, on the other hand, the downward trend in the employment rate only reinforces that of hours per worker.

\subsection{Some Implications}

While a number of papers have explored the consequences of introducing both margins of hours variations into a dynamic business cycle framework, I am not aware of any attempt to enrich those models with features that could help explain the low frequency changes in hours per worker and the employment rate highlighted above. ${ }^{13}$ To the extent that such low frequency variations are

\footnotetext{
${ }^{13} \mathrm{~A}$ possible exception, albeit in the context of a stylized model of wage-setting by unions/insiders with no explicit variation at the intensive margin, is found in Blanchard and
} 
due to factors orthogonal to the business cycle phenomena that those models seek to explain, abstracting from those features may be the right strategy when developing business cycle models. In particular, the secular decline in hours per worker observed in most countries would seem to fit that description. The same may be true for the observed long run trend in the employment rate in the U.S., Canada and Japan. In contrast, a look at the the low frequency variation of the latter variable in the continental European countries suggests a stronger connection to cyclical episodes.

Most importantly, and putting aside the implications for the theoretical modelling of the business cycle, the existence of such low frequency movements in hours is likely to impinge on empirical analyses and characterizations of economic fluctuations and their sources. The controversy, described below, regarding the appropriate transformation of hours in the recent empirical literature on the effects of technology shocks is a case in point. The evidence presented above, contrasts starkly with the assumption of stationarity in hours found in many empirical applications, and raises some doubts about any empirical findings that ignore the existence of those low frequency movements, while hinging on the assumption of stationary hours. Furthermore, as discussed below, the existence of a significant nonstationary component in hours per worker, implies that employment-based measures of productivity will be ridden with a nonstationary measurement error, which may question the validity of analyses that made use of those measures. That was the case, due to lack of data availability, for the international evidence on the effects of technology shocks reported in Galí (1999). In the next section I revisit that evidence using data on hours and hours-based productivity measures for the G7 countries.

Summers (1986). 


\section{International Evidence on the Effects of Tech- nology Shocks}

\subsection{Background}

The dynamic effects of technology shocks and their role as a source of economic fluctuations have been the focus of growing interest among macroeconomists. ${ }^{14}$ The bulk of the evidence generated by that literature has pointed to effects of technology very much at odds with the predictions of the standard RBC model. In particular, when technology shocks are identified in a structural VAR as the source of permanent shifts in labor productivity, they generate a negative comovement between hours and output (see, e.g., Galí (1999) and Francis and Ramey (2003)). Furthermore, and not surprisingly in light of the previous result, the implied estimated contribution of technology shocks to the variability of output and hours at business cycle frequencies tends to be very small, an observation which contrasts with the central role assigned to those shocks as a source of business cycles in the RBC literature. ${ }^{15}$

In a recent paper, Christiano, Eichenbaum and Vigfusson (2003; CEV, hereafter) have pointed to an apparent lack of robustness of the first finding (i.e., the negative response of hours to a positive technology shock) to the use of a VAR specification that includes the level of (log) hours, as opposed to detrended hours or its first difference as a labor input measure. More specifically, when CEV re-estimate the VAR using the level of $(\log )$ hours they find that a positive technology shock drives hours up, not down, and generates the positive comovement of hours and output that is the hallmark of the business cycle. ${ }^{16}$

\footnotetext{
${ }^{14}$ For a recent survey of that literature, see Galí and Rabanal (2004)

${ }^{15}$ Similar results are obtained in Basu et al. (2004) using a growth accounting approach to construct a measure of technological change. See also the references in the Galí and Rabanal (2004) survey.

${ }^{16}$ Yet, it is important to stress that their estimates of the contribution of technology shocks to the variance of output and hours is rather small, consistent with the findings in Galí (1999) and others.
} 
A recent paper by Fernald (2004) provides a convincing explanation for the discrepancy of the estimates of the effects of technology shocks when hours are introduced in levels. In particular he shows that the presence of a low frequency correlation between labor productivity growth and per capita hours, while unrelated to cyclical phenomena, distorts significantly the estimates of the short-run responses. Fernald illustrates that point most forcefully by reestimating the structural VAR in its levels specification (as in CEV), while allowing for two (statistically significant) trend breaks in labor productivity (in the mid-70s and mid-90s, respectively ), and showing that hours decline in response to a positive technology shock in the resulting estimates, in a way consistent with the findings obtained when the difference specification is used.

A different strategy is pursued by Francis and Ramey (2004b). Those authors construct an alternative time series for hours, with an annual frequency and spanning the entire 20th century. The Francis-Ramey series nomalizes total hours worked in the business sector using a population measure that excludes not only the population aged 16 and less (as in $\mathrm{CEV}$ ), but also the population older than 65 , as well as that enrolled in school or employed by the government. The resulting series for hours per capita is largely devoid of any of the nonstationary features that were apparent in the original series (as discussed in section 2). Most interestingly, though, when Francis and Ramey re-estimate the effects of technology shocks using the (log) level of the new series, they recover the findings associated with the detrended or first-differenced specification, i.e. a positive technology shock induces a short run decline in hours and a negative comovement between the latter variable and output. 


\subsection{New Evidence for the G7 countries}

Next I present some further evidence on the effects of technology shocks using data for the G7 countries. Motivated by the evidence and discussion in section 2, I treat (log) hours (as well as labor productivity) as a difference-stationary series. Accordingly, I estimate for each G7 country the structural model

$$
\left[\begin{array}{l}
\Delta x_{t} \\
\Delta n_{t}
\end{array}\right]=\left[\begin{array}{ll}
C^{11}(L) & C^{12}(L) \\
C^{21}(L) & C^{22}(L)
\end{array}\right]\left[\begin{array}{c}
\varepsilon_{t}^{z} \\
\varepsilon_{t}^{d}
\end{array}\right] \equiv C(L) \varepsilon_{t}
$$

where $\varepsilon_{t}^{z}$ and $\varepsilon_{t}^{d}$ are serially uncorrelated, mutually orthogonal structural disturbances, whose variance is normalized to unity. The polynomial $|C(z)|$ is assumed to have all its roots outside the unit circle. Estimates of the distributed lag polynomials $C^{i j}(L)$ are obtained by a suitable transformation of the estimated reduced form VAR for $\left[\Delta x_{t}, \Delta n_{t}\right]$ after imposing the long run identifying restriction $C^{12}(1)=0 .{ }^{17}$ That restriction effectively defines $\left\{\varepsilon_{t}^{z}\right\}$ and $\left\{\varepsilon_{t}^{d}\right\}$ as shocks with and without a permanent effect on labor productivity, respectively. On the basis of some of the steady state restrictions shared by a broad range of macro models I interpret permanent shocks to productivity $\left\{\varepsilon_{t}^{z}\right\}$ as technology shocks. On the other hand, transitory shocks $\left\{\varepsilon_{t}^{d}\right\}$ can potentially capture a variety of driving forces behind output and labor input fluctuations that would not be expected to have permanent effects on labor productivity. The reader is referred to Galí (1999) and Francis and Ramey (2003) for a detailed discussion.

A number of recent papers have provided related evidence using data for countries other than the U.S., as surveyed in Galí and Rabanal (2004). Here I revisit some earlier evidence using international data, which the findings of section 2 might call into question. Thus, in Galí (1999, 2004) and Francis, Owyang, and Theodorou (2004) a similar structural VAR-based approach is applied to G7 countries' quarterly data. In that exercise Galí (1999) used both

\footnotetext{
${ }^{17}$ See Blanchard and Quah (1989) and Galí (1999) for details.
} 
first-differenced and detrended (log) employment as a measure of labor input, obtaining a negative response of employment to a positive technology shock in all countries, with the exception of Japan. Similar qualitative results for the euro area as a whole are found in Galí (2004), where I used the quarterly data set for the euro area recently constructed by Fagan et al. (2001), also using employment as a measure of labor input. ${ }^{18}$ Francis et al. (2004) used first-differenced (log) employment, together with other macro variables, focusing on the potential role of monetary policy factors in shaping the response to technology shocks.

In light of the evidence and discussion found in section 2, the use of employment as a measure of labor input raises a potential problem. First, and to the extent that hours per worker vary over time, employment-based measures of labor productivity will be ridden with error. Most importantly, however, the presence of a possible nonstationary component in hours per worker undermines the theoretical basis for the identification strategy used in that work. In particular, it implies that factors other than technology may generate permanent shifts in measures of output per worker-and hence may be incorrectly labeled as technology shocks-, even if they do not have any long run effect on "true" labor productivity (i.e., output per hour). The availability of (relatively long) homogeneous time series for hours worked in a number of OECD countries allows one to overcome the above problem. Next I describe the evidence on the effects of technology shocks obtained by applying the structural VAR framework above to hours-based measures of productivity and labor input for the G7 countries.

The top graph in the top panel of Figures 4.A-4.G display, for each G7 country the growth rates of GDP and hours over the period 1970-2002. As it is clear to the eye, both series display a strong positive comovement, which can be

\footnotetext{
${ }^{18}$ In particular, technology shocks are found to account for only 5 percent and 9 percent of the variance of the business cycle component of euro area employment and output, respectively, with the corresponding correlation between their technology-driven components being -0.67 ).
} 
viewed as one of the defining features of the business cycle. The corresponding unconditional correlations, reported in the third column of Table 3, range from 0.30 (Italy) to 0.84 (US). The second graph shows the components of GDP and hours growth associated with technology shocks, while the third graph shows the component driven by other (non-technology) sources. With the exception of the UK and Japan, the comovement of hours and GDP growth generated by technology shocks is much smaller than that observed in the original data. As shown in Table 3, that conditional correlation is even negative in some cases (US, Italy, and France), and very small in others (Germany and Canada). The first two columns of Table 3, which show the estimated contribution of technology shocks to the variance of GDP and hours growth, suggest a limited role of technology shocks as a source of fluctuations in the growth rates of either GDP or hours. In particular, technology shocks account for more than 50 percent of the variance of hours growth only in Italy and the U.K., though as discussed below, this can hardly be attributed to the mechanisms underlying RBC model.

A look at the estimated impulse responses of labor productivity, GDP, and hours to a positive technology shock (i.e., one that raises productivity) helps understand the previous patterns. Those impulse responses (together with a \pm 2 standard errors confidence interval) are displayed in the bottom panel of Figures 4.A through 4.G. The sign of the point estimate for the impact responses of GDP and hours is also reported in Table 3. For all countries but Japan, a positive technology shock generates either a negligible response of hours or a short run decline in that variable, in contrast with the predictions of the standard RBC model. With the exception of the UK, the corresponding response of output to the same shock is positive. It is thus not surprising that for the remaining countries (US, Canada, Germany, Italy, and France) technology shocks do not make the large contribution to the variance of both GDP and hours growth that 
proponents of the $\mathrm{RBC}$ paradigm would have led us to expect. In fact, a look at Table 3 suggests that the pattern of conditional second moments and impulse responses that one would associate with an RBC model that were capable of accounting for the bulk of GDP and hours fluctuations can only be found for Japan. Why the latter country (as well as the UK) displays a pattern different from the rest is beyond the scope of this paper.

\section{Summary and Conclusions}

The present paper has revisited the empirical and theoretical grounds for a property found in most dynamic macroeconomic models, namely, that of stationarity of hours worked per capita. From a theoretical viewpoint, I have argued that stationarity of hours per capita is not a necessary condition in order for a macro model to generate a balanced growth path. One can think of many factors that could lead to nonstationary hours, including permanent shifts in government purchases or in labor and product market wedges, as well as permanent preference shifts. In fact, it is hard to imagine why some of those factors would remain unchanged or display only transitory fluctuations.

From an empirical perspective, I have shown that the evidence for most industrialized economies appears to be at odds with the equilibrium relationships that are at the root of the property of stationarity in hours per capita. In fact, that evidence suggests that both margins of labor utilization (i.e., hours per worker and the employment rate) display some nonstationarity features in most countries.

Finally, I have revisited the international evidence on the effects of technology shocks using a measure of output per hour for the G7 countries. That measure overcomes the potential identification problems that may have resulted

from using an employment-based measure of productivity, given the evidence of 
significant nonstationarity in hours per worker. The findings from that exercise suggest that, possibly with the exception of Japan, the evidence on the effects of technology shocks shows major discrepancies with the predictions of standard real business cycle models. 


\section{Appendix: Hours Worked and the Consumption Share in a Two-Sector Model}

The first order condition of the household problem is:

$$
w_{t}-p_{t}^{c}=c_{t}+\varphi n_{t}
$$

where $p_{t}^{c}$ denotes the price of consumption goods.

The first order condition for a firm producing consumption goods is

$$
w_{t}-p_{t}^{c}=y_{t}^{c}-n_{t}^{c}
$$

whereas the one for firms in the investment goods sector is

$$
w_{t}-p_{t}^{i}=y_{t}^{i}-n_{t}^{i}
$$

A weighted average of the previous conditions imply

$$
w_{t}-p_{t}=y_{t}-n_{t}
$$

which, combined with the expression derived above, yields

$$
\left(p_{t}+y_{t}\right)=\left(p_{t}^{c}+c_{t}\right)+(1+\varphi) n_{t}
$$

Letting $s_{c, t} \equiv\left(p_{t}^{c}+c_{t}\right)-\left(p_{t}+y_{t}\right)$ denote the (log) ratio of nominal consumption to nominal output, and rearranging terms yields equation (1) in the text. 


\section{References}

Basu, Susanto, John Fernald, and Miles Kimball (2004): "Are Technology Improvements Contractionary?," American Economic Review, forthcoming.

Baxter, Marianne, and Robert G. King (1999), "Measuring Business Cycles: Approximate Band-Pass Filters for Economic Time Series," The Review of Economics and Statistics, 81(4), 575-593.

Blanchard, Olivier J. and Lawrence Summers (1986): "Hysteresis and the European Unemployment Problem," NBER Macroeconomics Annual, 15-77.

Chari, V.V., Patrick J. Kehoe, and Ellen McGrattan (2004): "An Economic Test of Structural VARs," Federal Reserve Bank of Minneapolis, Research Department Staff Report 345.

Christiano, Larry, Martin Eichenbaum and Charles Evans (2003), "Nominal Rigidities and the Dynamic Effects of a Shock to a Monetary Policy", Journal of Political Economy, forthcoming.

Christiano, Lawrence, Martin Eichenbaum, and Robert Vigfusson (2003): "What Happens after a Technology Shock?," NBER WP\# 9819.

Cooley, Thomas F., and Edward C. Prescott (1995): "Economic Growth and Business Cycles," in T.F. Cooley ed., Frontiers of Business Cycle Research, Princeton University Press.

Erceg, Christopher J., Luca Guerrieri, and Christopher Gust (2004): "Can Long Run Restrictions Identify Technology Shocks?," Federal Reserve Board, mimeo.

Fagan, Gabriel, Jerome Henry, and Ricardo Mestre (2001): "An Area-Wide Model (AWM) for the euro area" ECB Working Paper no. 42.

Fernald, John (2004): "Trend Breaks, Long Run Restrictions, and the Contractionary effects of a Technology Shock," mimeo, Federal Reserve Bank of Chicago. 
Francis, Neville, Michael T. Owyang, and Athena T. Theodorou (2004): "What Explains the Varying Monetary Response to Technology Shocks in G-7 Countries?," Federal Reserve Bank of St. Louis, Working Paper 2004-002C.

Francis, Neville, and Valerie Ramey (2003), "Is the Technology-Driven Real Business Cycle Hypothesis Dead? Shocks and Aggregate Fluctuations Revisited," Journal of Monetary Economics, forthcoming.

Francis, Neville, and Valerie Ramey (2004a): "The Source of Historical Economic Fluctuations: An Analysis using Long-Run Restrictions," NBER WP\# 10631.

Francis, Neville, and Valerie Ramey (2004b): "A New Measure of Hours per Capita with Implications for the Technology-Hours Debate," mimeo.

Galí, Jordi (1999): "Technology, Employment, and the Business Cycle: Do Technology Shocks Explain Aggregate Fluctuations?," American Economic Review, vol. 89, no. 1, 249-271.

Galí, Jordi (2003): "New Perspectives on Monetary Policy, Inflation, and the Business Cycle," in Advances in Economics and Econometrics, volume III, edited by M. Dewatripont, L. Hansen, and S. Turnovsky, Cambridge University Press (NBER WP \#8767).

Galí, Jordi (2004): "On the Role of Technology Shocks as a source of Business Cycles: Some New Evidence," Journal of the European Economic Association, vol. 2, issue 2-3, 372-380.

Galí, Jordi, Mark Gertler, and David López-Salido (2003): "Markups, Gaps and the Welfare costs of Business Fluctuations," mimeo.

Galí, Jordi and Pau Rabanal (2004): "Technology Shocks and Aggregate Fluctuations: How Well Does the Real Business Cycle Model Fit Postwar U.S. Data?," NBER Macroeconomics Annual, forthcoming. (also NBER WP\#10636). Hall, Robert, E. (1997): "Macroeconomic Fluctuations and the Allocation 
of Time", Journal of Labor Economics, vol.15,no.1,pt.2. 1997, S223-S250.

King, Robert G., Charles Plosser, and Sergio T. Rebelo (1988): "Production, Growth and Business Cycles: I. the Basic Neoclassical Model," Journal of Monetary Economics 21, 195-232.

King, Robert G.and Sergio T. Rebelo (1999): "Resuscitating Real Business Cycles":in J.B. Taylor and M. Woodford eds., Handbook of Macroeconomics, volume 1B, 928-1002 (also NBER WP 7534).

Kydland, Finn E. and Edward C. Prescott (1982): "Time to Build and Aggregate Fluctuations, “ Econometrica 50, 1345-1370.

McGrattan, Ellen R. and Richard Rogerson: "Changes in Hours Worked, 1950-2000," Quarterly Review, Federal Reserve Bank of Minneapolis, July, 1433.

Mulligan, Casey (2002): "A Century of Labor-Leisure Distortions," NBER WP\# 8774.

Prescott, Edward C. (1986a): "Theory Ahead of Business Cycle Measurement," Quarterly Review 10, 9-22, Federal Reserve Bank of Minneapolis.

Prescott, Edward C. (2004): "Why Do Americans Work So Much More Than Europeans?," Quarterly Review, Federal Reserve Bank of Minneapolis.

Sbordone, Argia (2000): “An Optimizing Model of U.S. Wage and Price Dynamics," mimeo.

Stock, James, and Mark W. Watson (1999): "Business Cycle Fluctuations in U.S. Macroeconomic Time Series," in J.B. Taylor and M. Woodford eds., Handbook of Macroeconomics, volume 1A, 3-64 (also NBER WP 6528).

Whelan, Karl (2004): "Technology Shocks and Hours Worked: Checking for Robust Conclusions," mimeo.

Whelan, Karl (2004): "New Evidence on Balanced Growth, Stochastic Trends, and Economic Fluctuations," mimeo. 


\section{Table 1}

\section{Comovement of Hours and the Consumption Share: U.S. Evidence}

\begin{tabular}{|c|c|c|c|c|}
\hline & \multicolumn{2}{|c|}{ Log - levels } & \multicolumn{2}{|c|}{$\begin{array}{c}\text { Business Cycle } \\
\text { Component }\end{array}$} \\
\hline & $s_{c}$ & $\rho$ & $s_{c}$ & $\rho$ \\
\hline & \multicolumn{4}{|c|}{ Nonfarm Business Hours } \\
\hline Nondurables and Services, Private & $\begin{array}{c}0.16 \\
(0.05)\end{array}$ & 0.19 & $\begin{array}{l}-1.26 \\
(0.06)\end{array}$ & -0.78 \\
\hline Total Private Consumption & $\begin{array}{c}0.25 \\
(0.06)\end{array}$ & 0.25 & $\begin{array}{l}-1.32 \\
(0.08)\end{array}$ & -0.71 \\
\hline \multirow[t]{2}{*}{ Total Consumption } & $\begin{array}{c}0.01 \\
(0.04)\end{array}$ & 0.04 & $\begin{array}{l}-1-14 \\
(0.05)\end{array}$ & -0.76 \\
\hline & \multicolumn{4}{|c|}{ Total Hours } \\
\hline Nondurables and Services, Private & $\begin{array}{c}0.84 \\
(0.06)\end{array}$ & 0.66 & $\begin{array}{l}-1.28 \\
(0.05)\end{array}$ & -0.85 \\
\hline Total Private Consumption & $\begin{array}{c}1.00 \\
(0.07)\end{array}$ & 0.68 & $\begin{array}{l}-1.17 \\
(0.08)\end{array}$ & -0.67 \\
\hline Total Consumption & $\begin{array}{c}0.69 \\
(0.04)\end{array}$ & 0.71 & $\begin{array}{l}-1.13 \\
(0.04)\end{array}$ & -0.74 \\
\hline
\end{tabular}




\section{Table 2}

\section{Comovement of Hours and the Consumption Share:}

\section{International Evidence}

\begin{tabular}{|l|c|c|}
\hline & \multicolumn{2}{|c|}{ Correlation between $\boldsymbol{n}$ and $\boldsymbol{s}_{\boldsymbol{c}}$} \\
\hline & Levels & First Differences \\
\hline US & 0.80 & -0.57 \\
\hline & & \\
\hline Canada & 0.23 & -0.53 \\
\hline & & -0.49 \\
\hline Japan & -0.73 & -0.10 \\
\hline & -0.09 & -0.47 \\
\hline UK & -0.07 & -0.53 \\
\hline \multicolumn{2}{|l|}{} \\
\hline France & 0.26 & 0.01 \\
\hline & -0.41 & \\
\hline Germany & & \\
\hline \multicolumn{2}{|l|}{} \\
\hline Italy & & \\
\hline & & \\
\hline Data: OECD Labor Force Statistics Database and Annual National \\
Income Accounts
\end{tabular}




\section{Table 3}

\section{Technology Shocks and Business Cycles: International Evidence}

\begin{tabular}{|c|c|c|c|c|c|c|}
\hline & \multicolumn{2}{|c|}{ Variance share } & \multicolumn{2}{|c|}{ Correlation $(\Delta \mathbf{n}, \Delta \mathbf{y})$} & \multicolumn{2}{|c|}{ Impact Response } \\
\hline & $\operatorname{var}(\Delta y)$ & $\operatorname{var}(\Delta \mathrm{n})$ & Unconditional & Conditional & Hours & GDP \\
\hline US & 0.09 & 0.02 & 0.84 & -0.79 & - & + \\
\hline Canada & 0.12 & 0.24 & 0.83 & 0.24 & - & + \\
\hline Japan & 0.88 & 0.40 & 0.70 & 0.89 & + & + \\
\hline UK & 0.54 & 0.74 & 0.76 & 0.93 & - & - \\
\hline Germany & 0.17 & 0.11 & 0.73 & 0.07 & - & + \\
\hline Italy & 0.13 & 0.65 & 0.30 & -0.26 & - & + \\
\hline France & 0.54 & 0.07 & 0.56 & -0.32 & - & + \\
\hline & & & & & & \\
\hline
\end{tabular}


Figure 1. Hours and the Consumption Share: U.S. Evidence Nondurables and Services
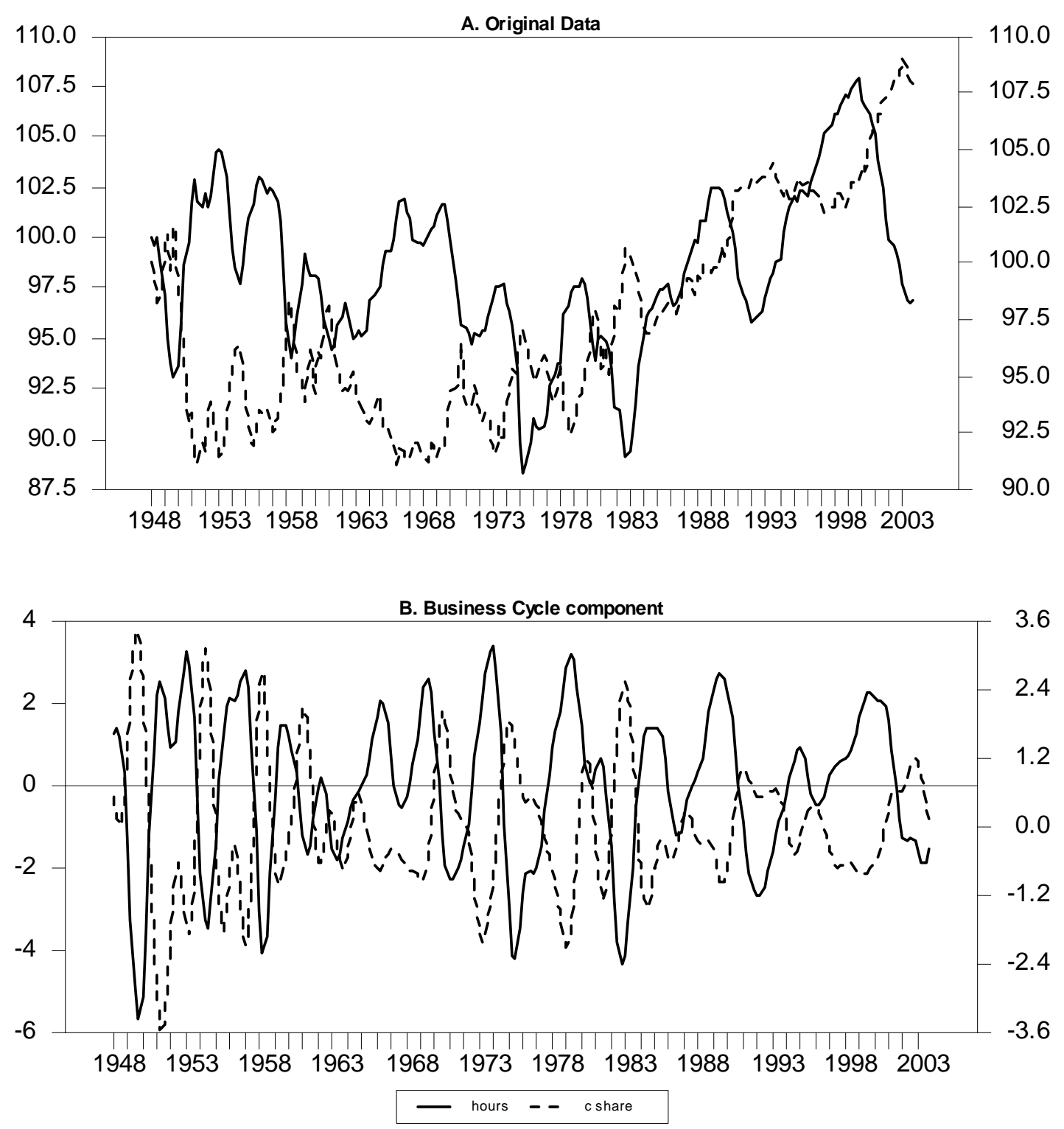
Figure 2. Hours and the Consumption Share: International Evidence

Hours (solid), Consumption share (dashed)
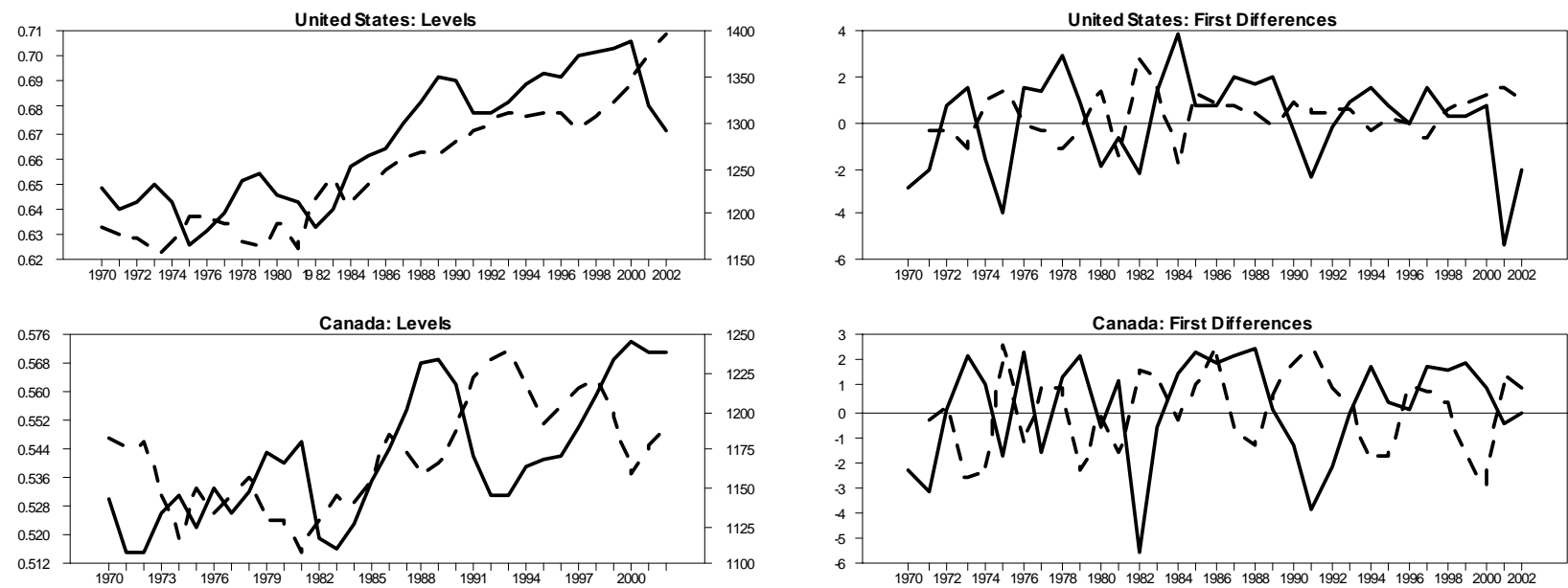

$\begin{array}{llllllllllllllllllllll}1970 & 1972 & 1974 & 1976 & 1978 & 1980 & 1982 & 1984 & 1986 & 1988 & 1990 & 1992 & 1994 & 1996 & 1998 & 2000 & 2002\end{array}$
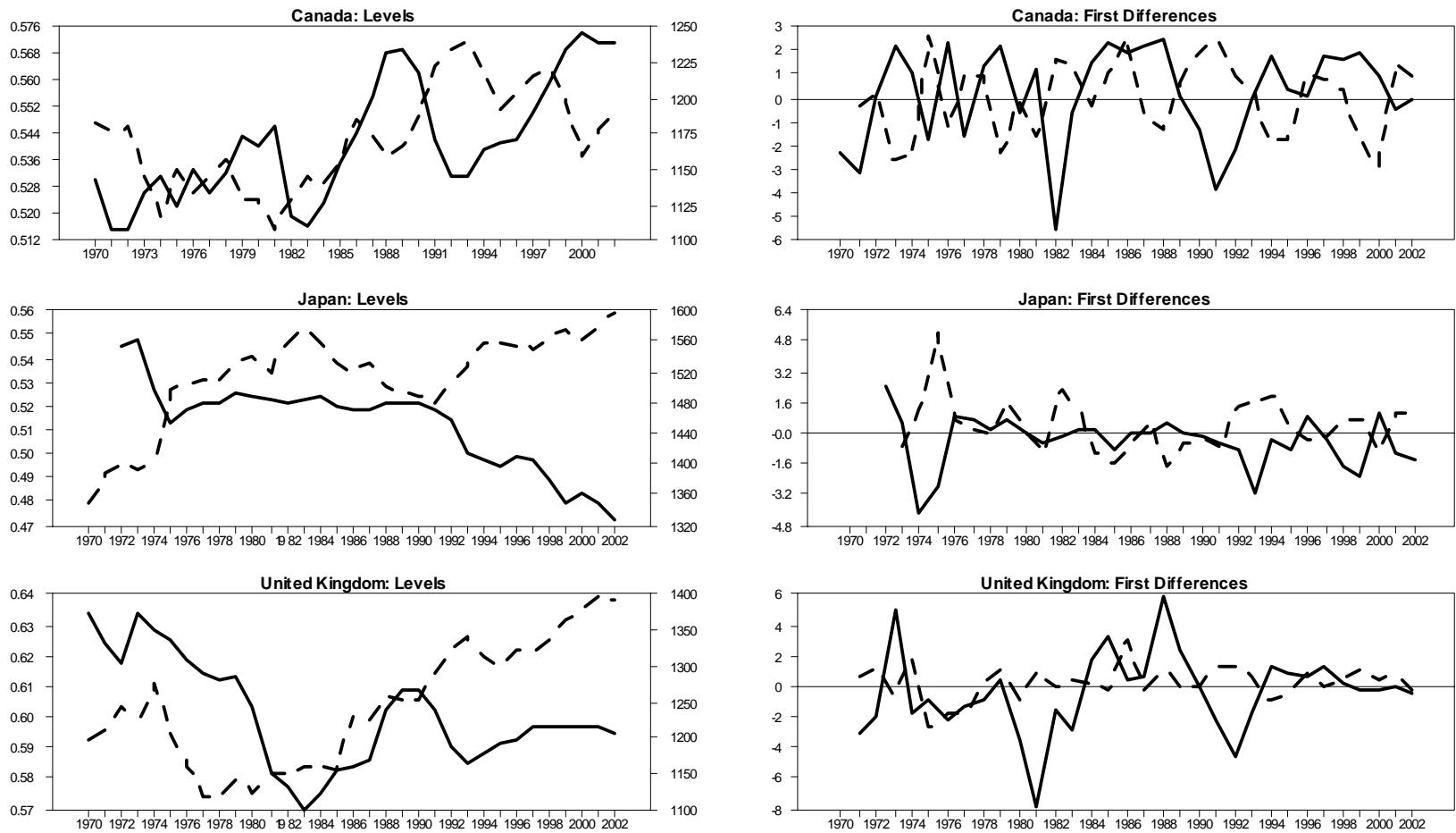

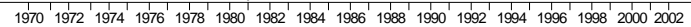
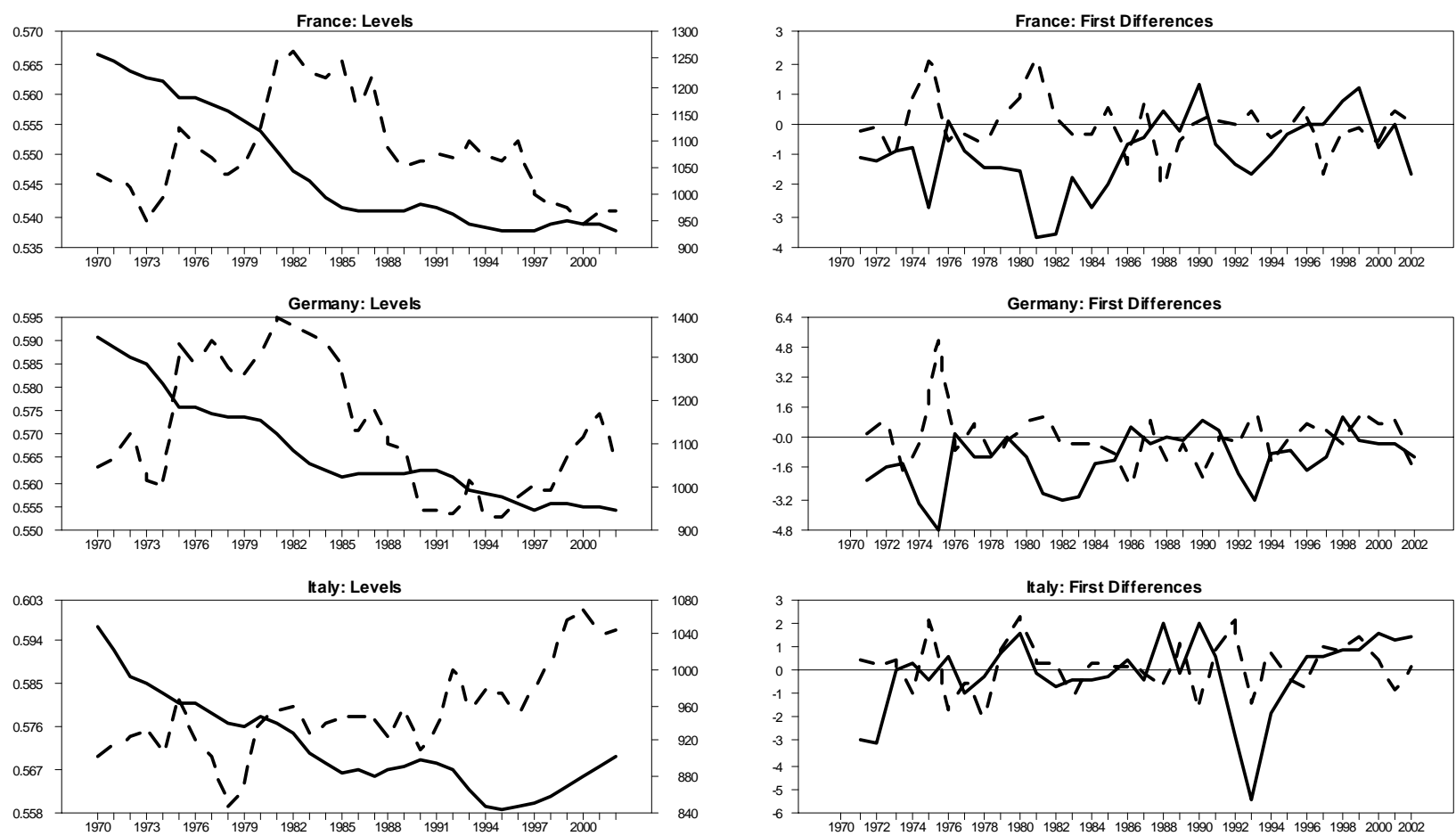

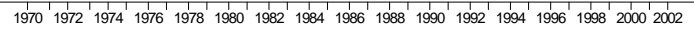


Figure 3.A

Labor Force Statistics: United States

Hours per Capita

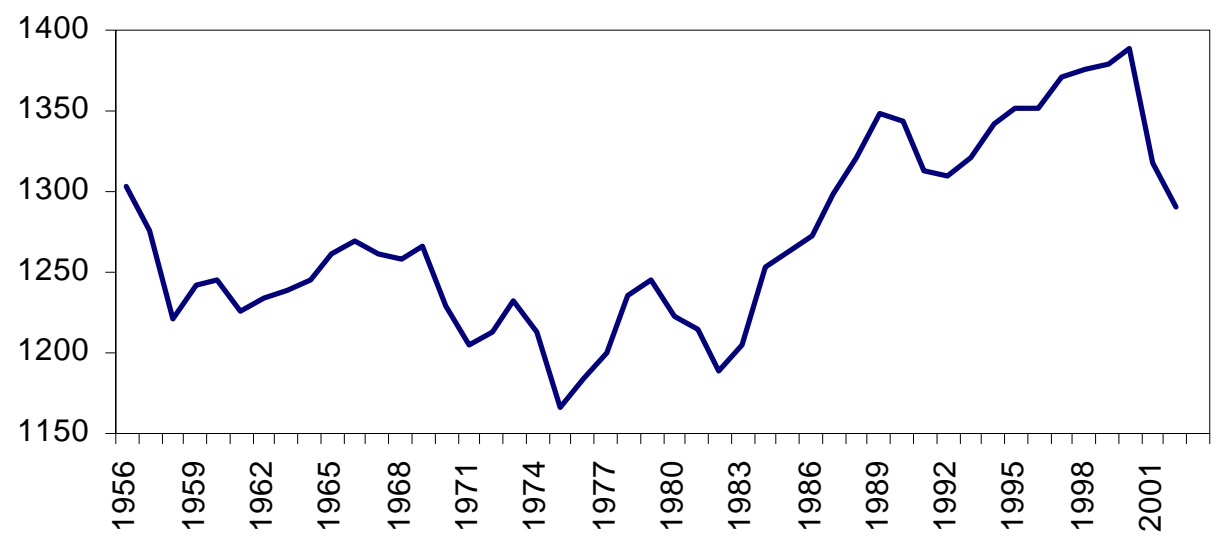

Hours per Worker

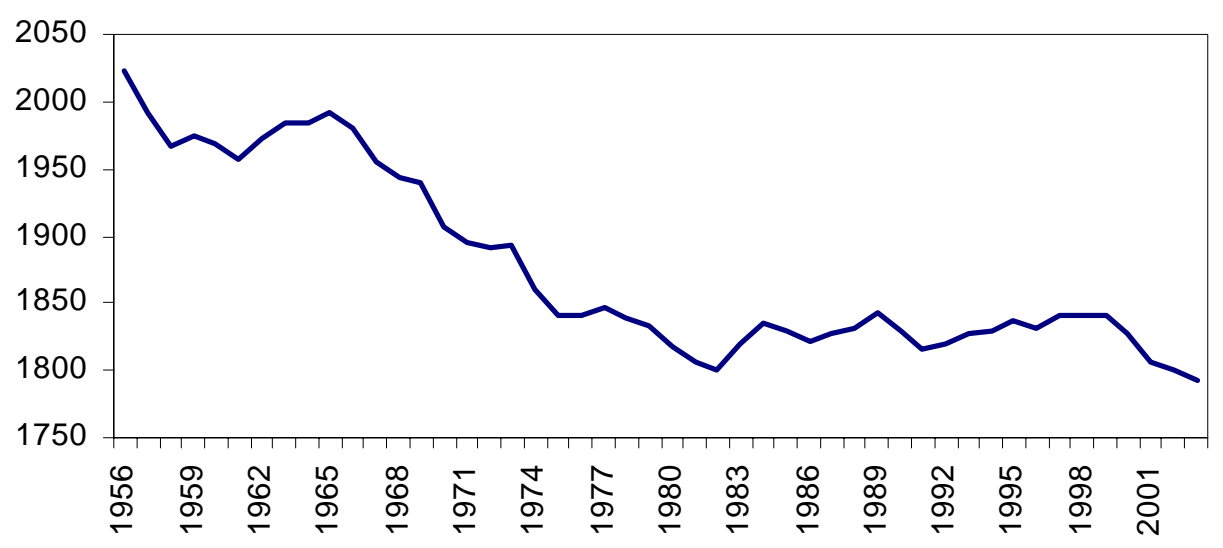

Employment Ratio

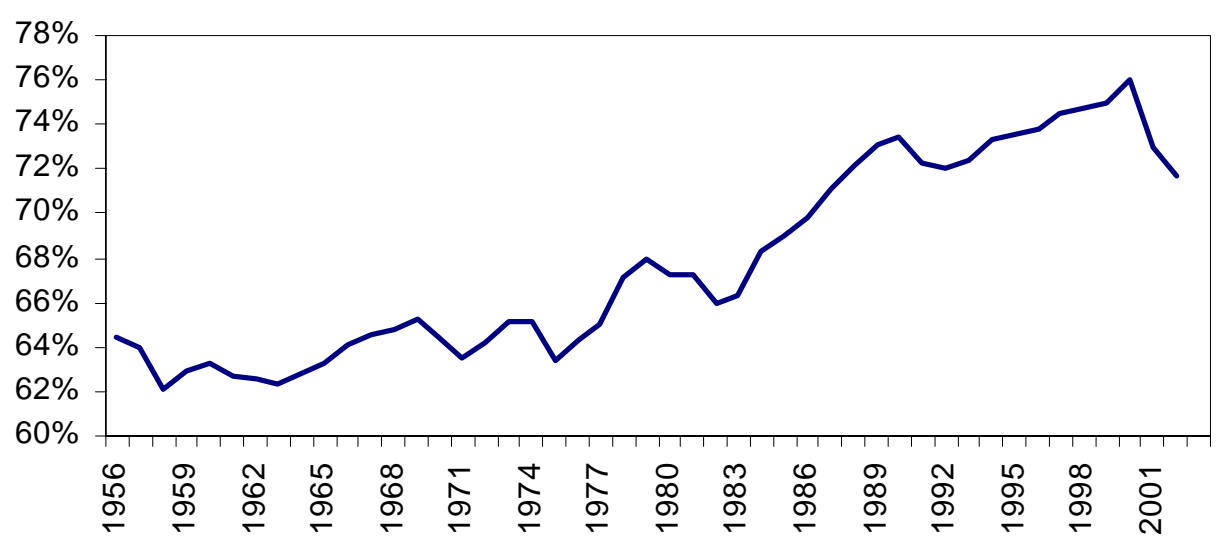


Figure 3.B

Labor Force Statistics: Canada

Hours per Capita

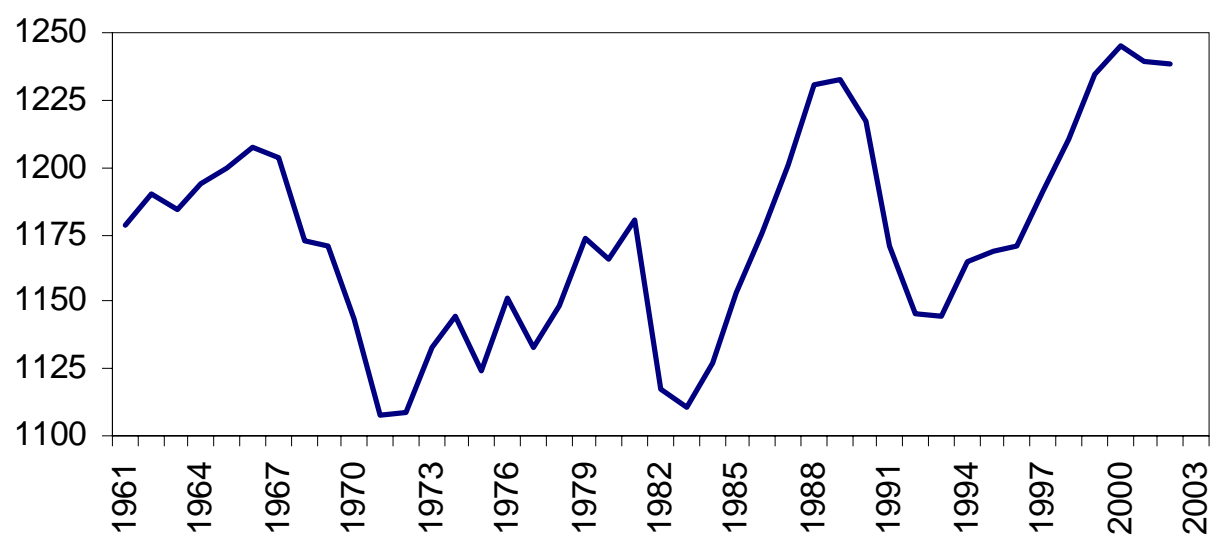

Hours per Worker

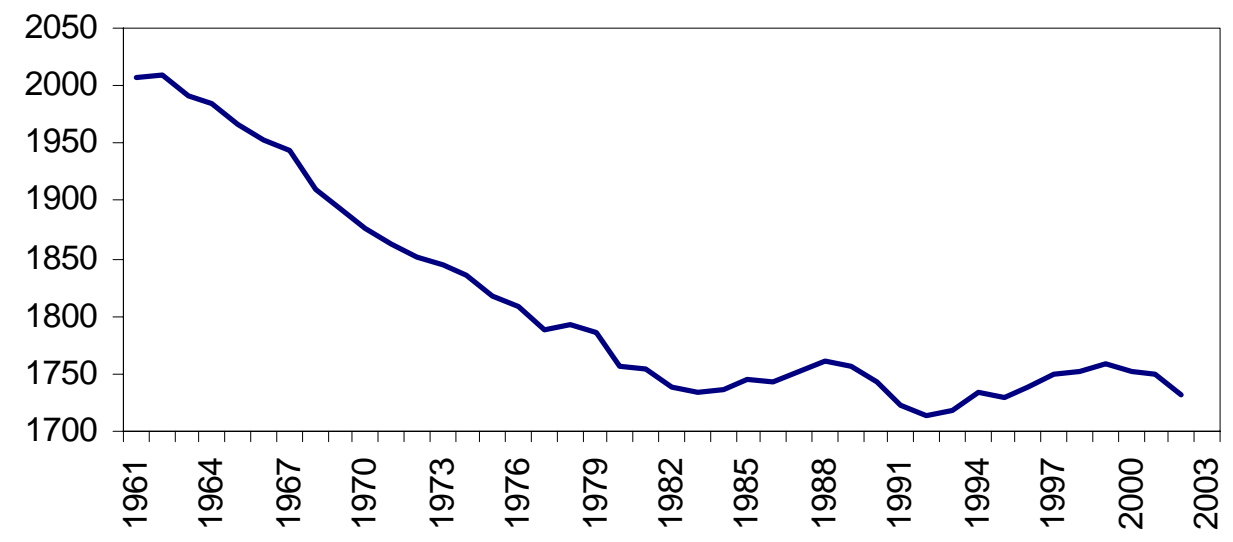

Employment Ratio

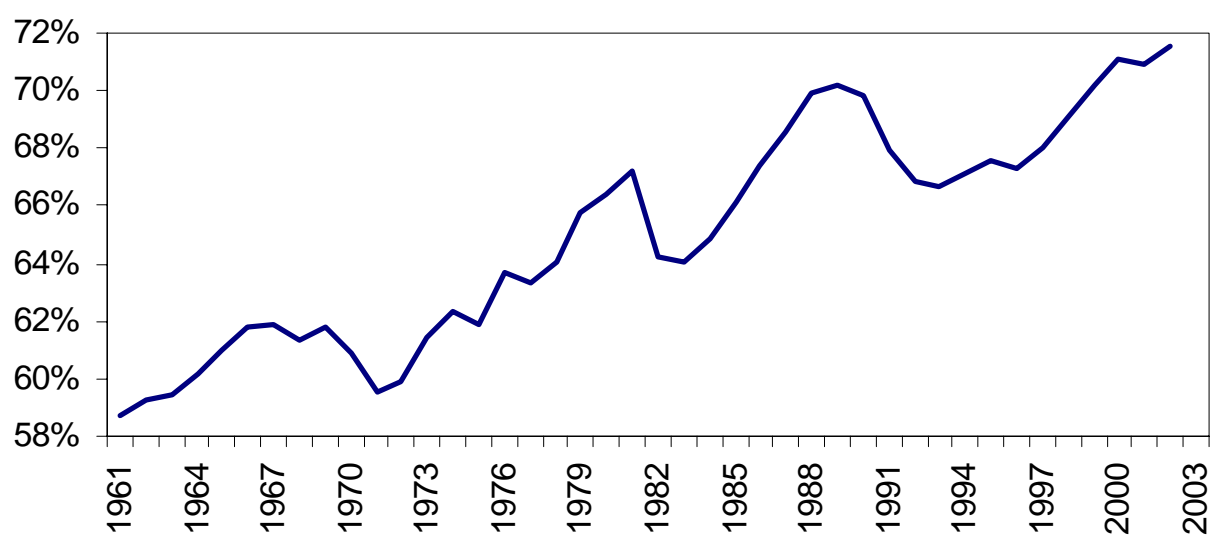


Figure 3.C

Labor Force Statistics: Japan

Hours per Capita

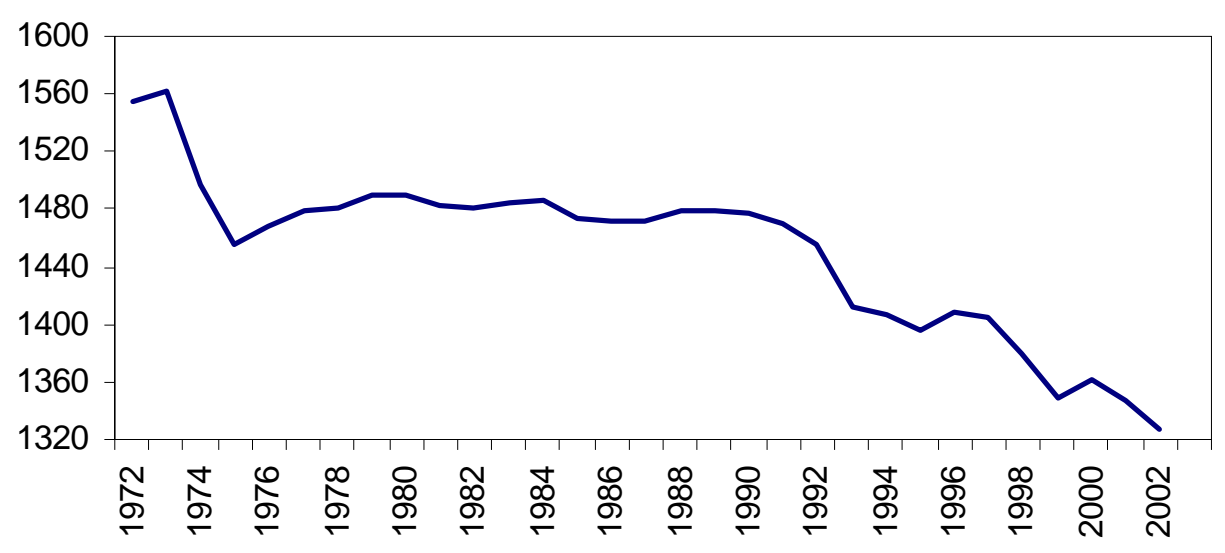

Hours per Worker

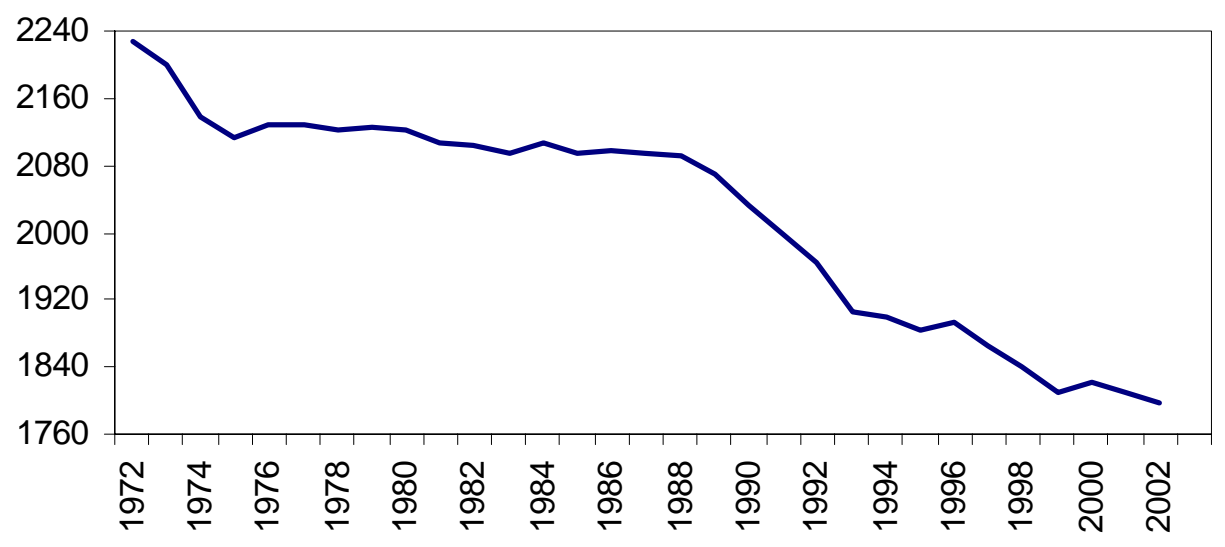

Employment Ratio

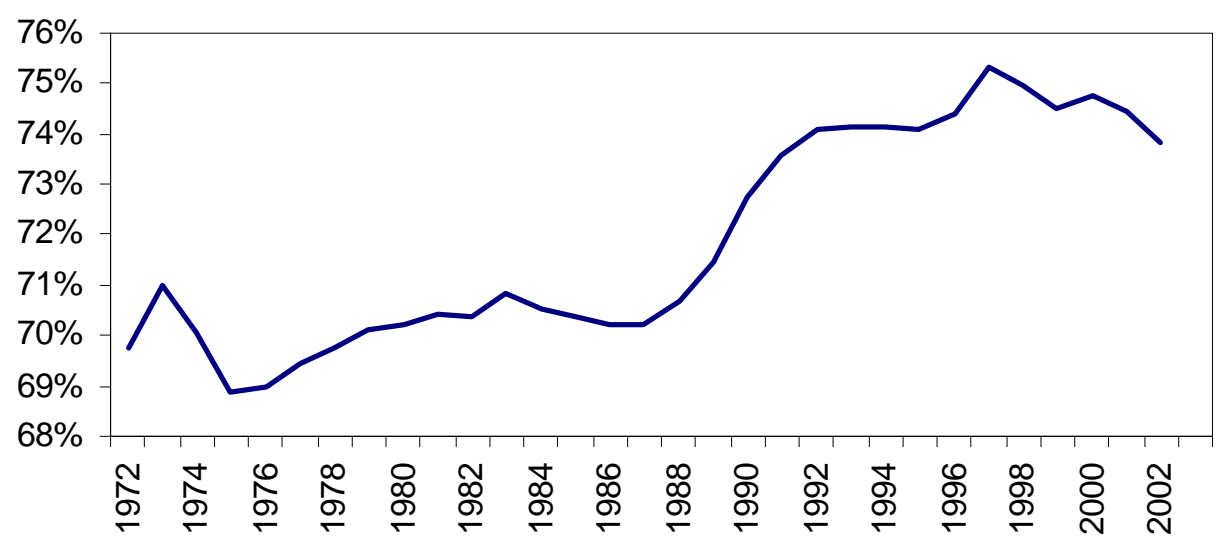


Figure 3.D

Labor Force Statistics: United Kingdom

Hours per Capita

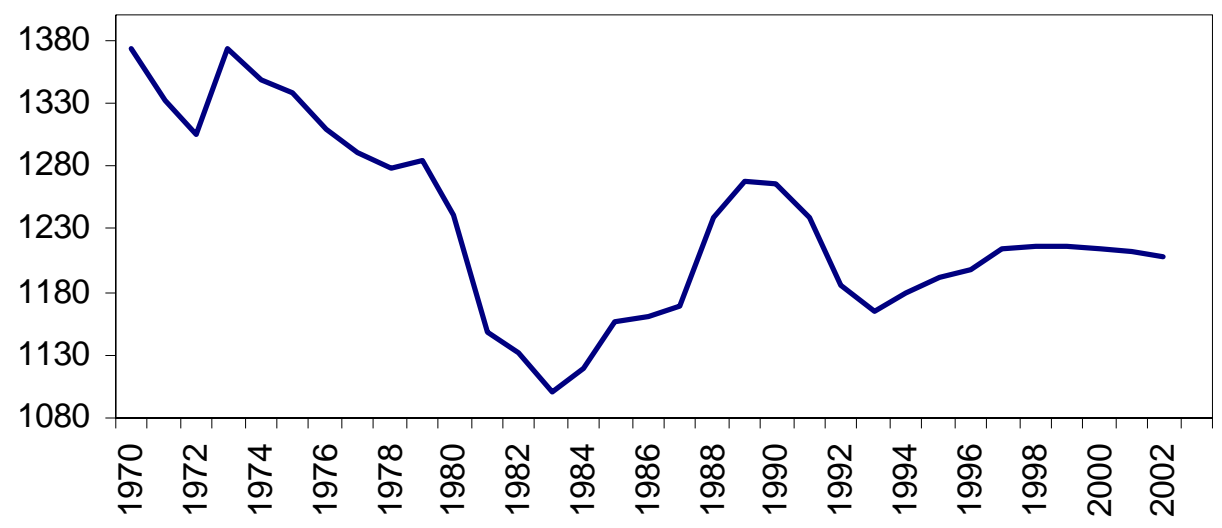

Hours per Worker

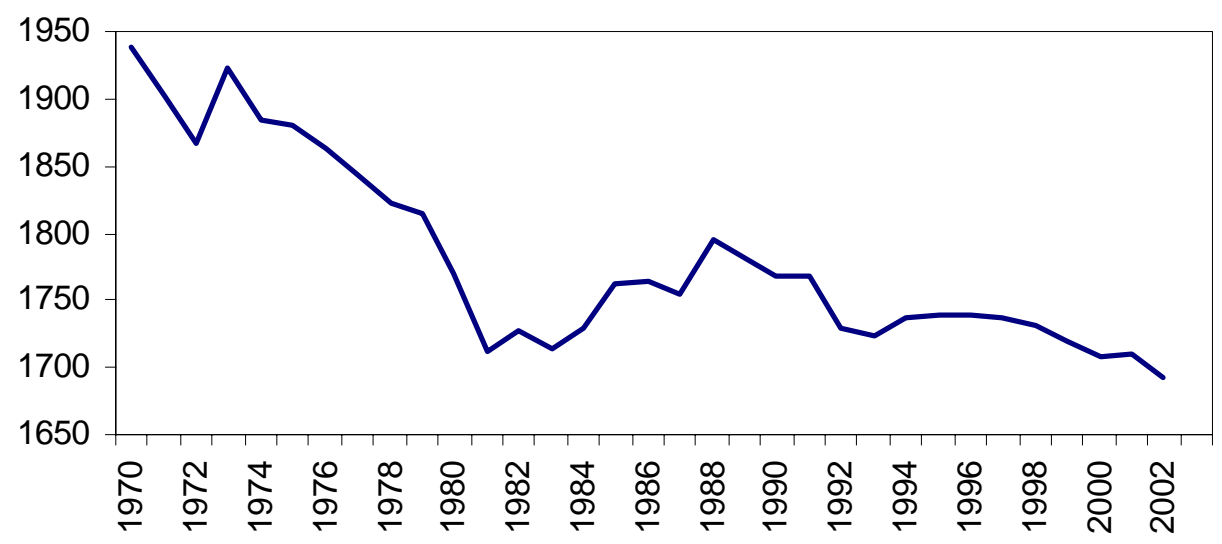

\section{Employment Ratio}

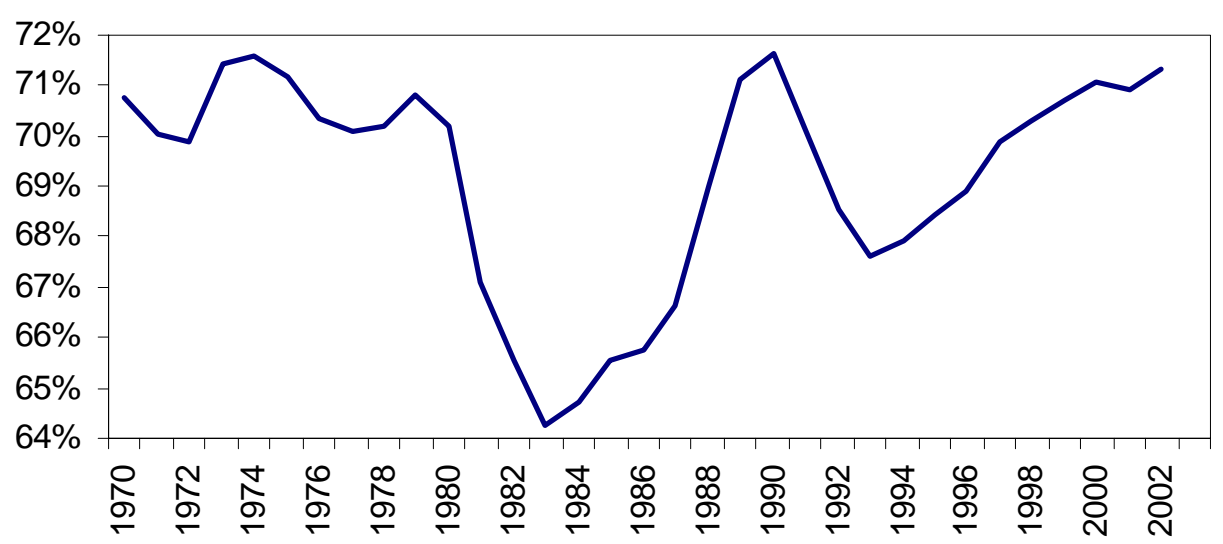


Figure 3.E

Labor Force Statistics: France

\section{Hours per Capita}

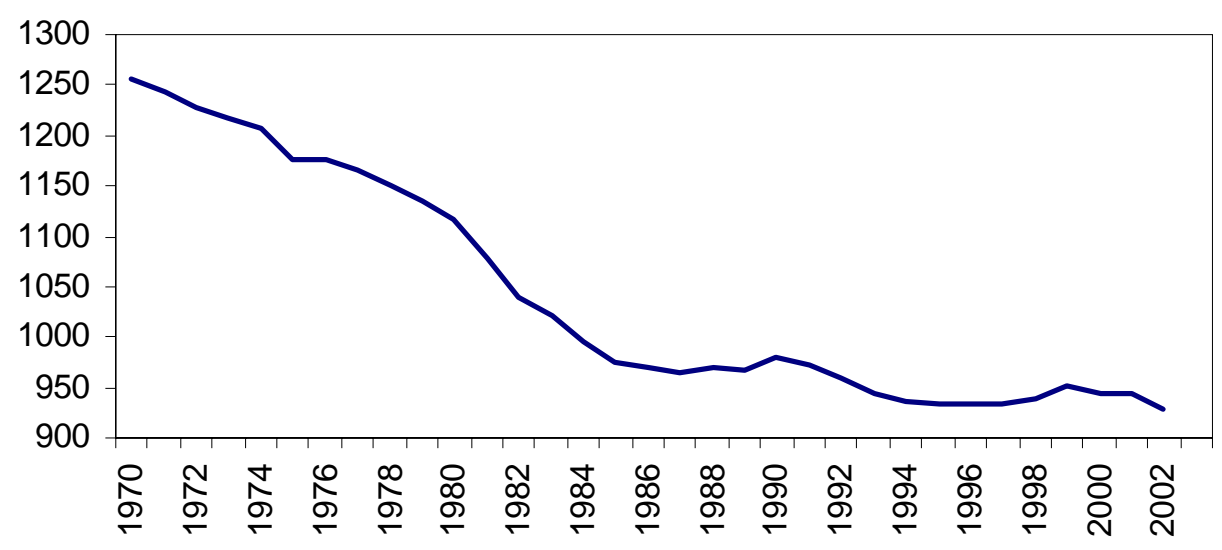

Hours per Worker

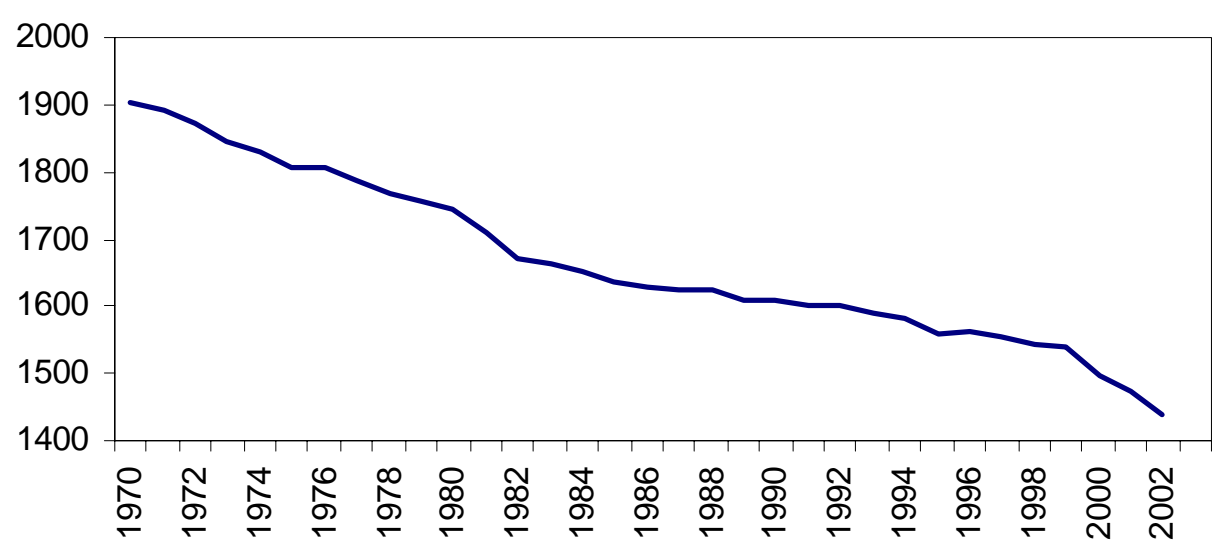

Employment Ratio

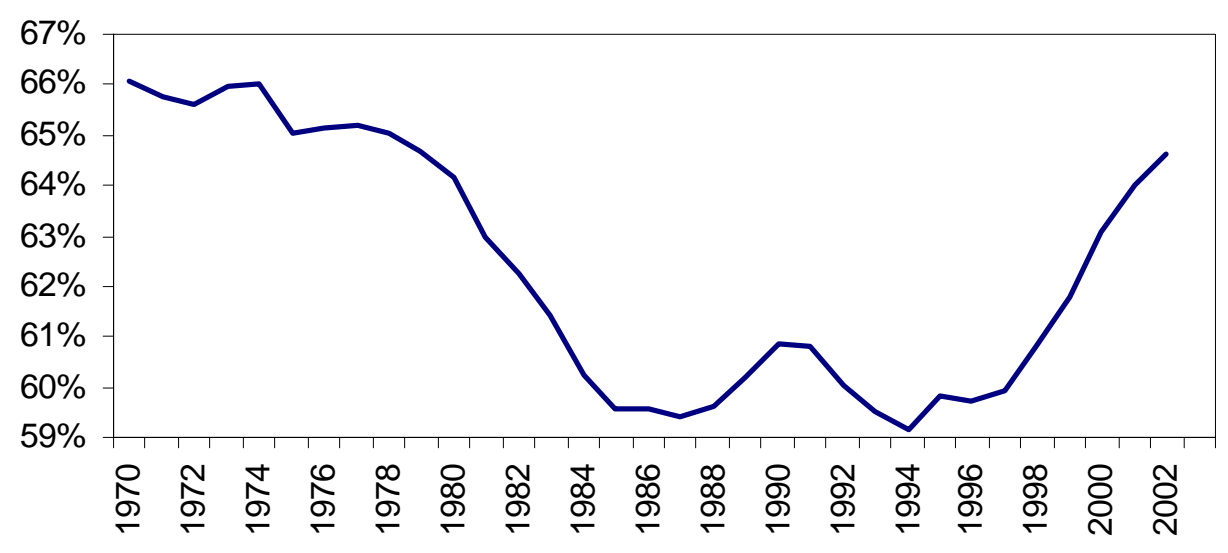


Figure 3.F

Labor Force Statistics: Germany

Hours per Capita

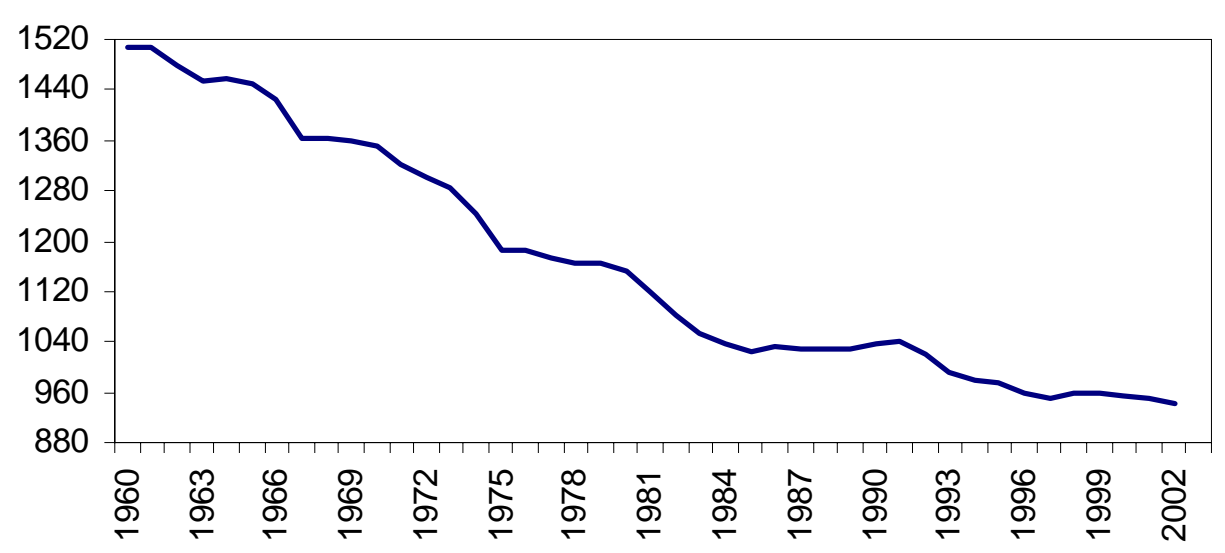

Hours per Worker

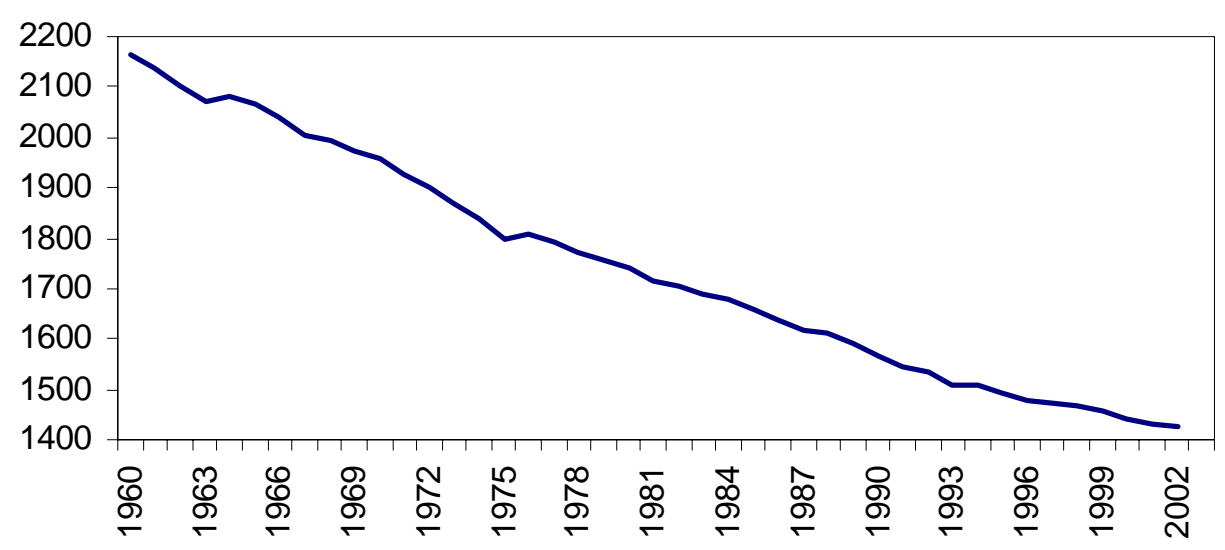

Employment Ratio

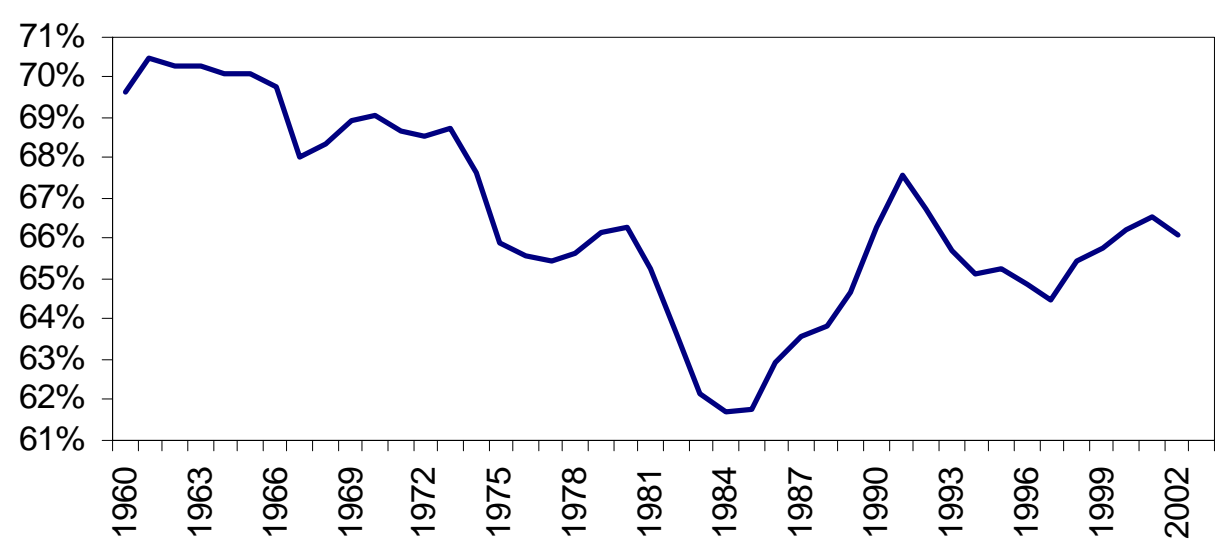


Figure 3.G

Labor Force Statistics: Italy

Hours per Capita

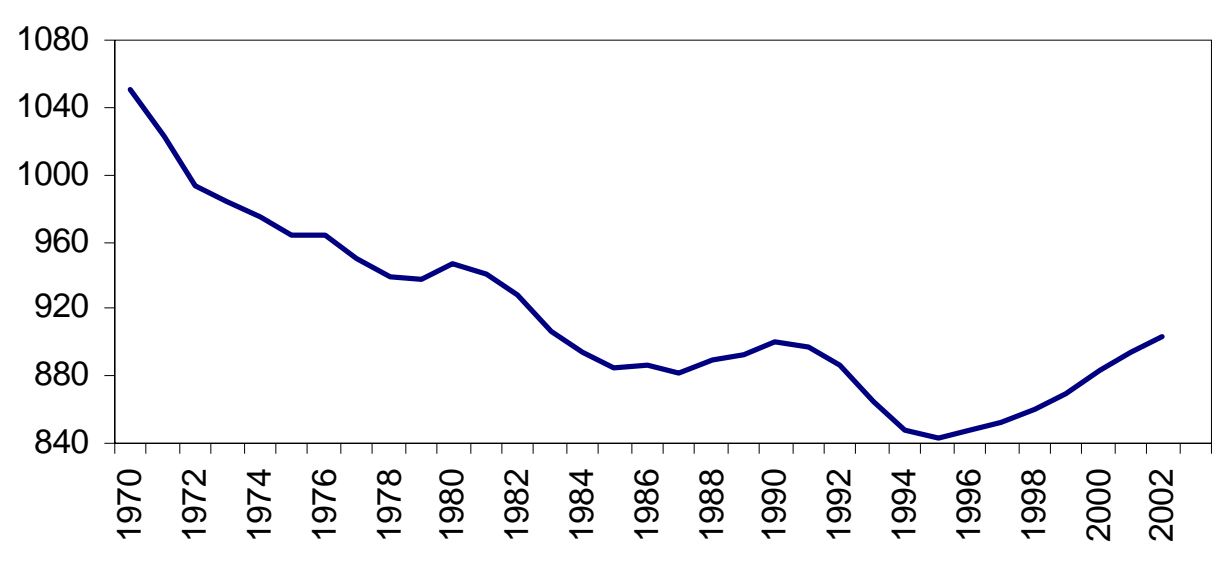

Hours per Worker

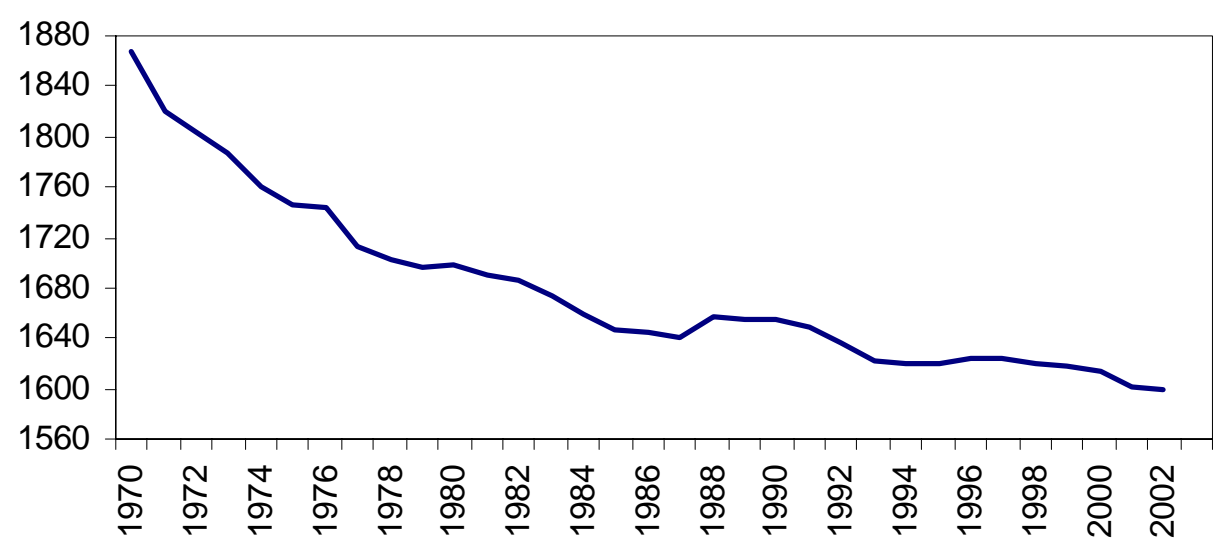

Employment Ratio

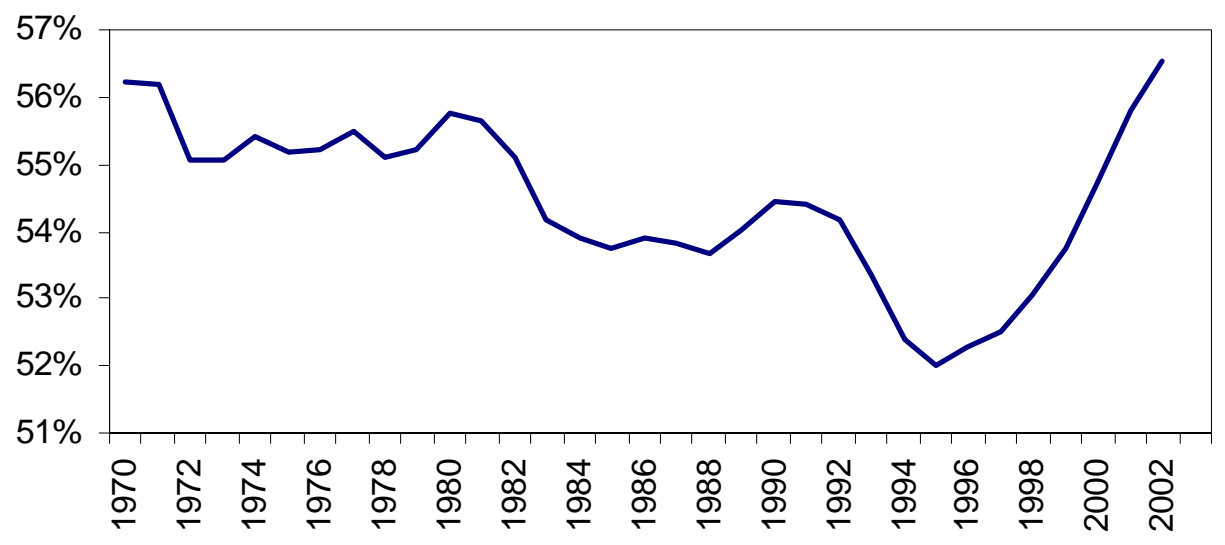




\section{FIGURE 4.A}

Fluctuations and its Sources: United S tates GDP and Hours: Annual Growth Rates
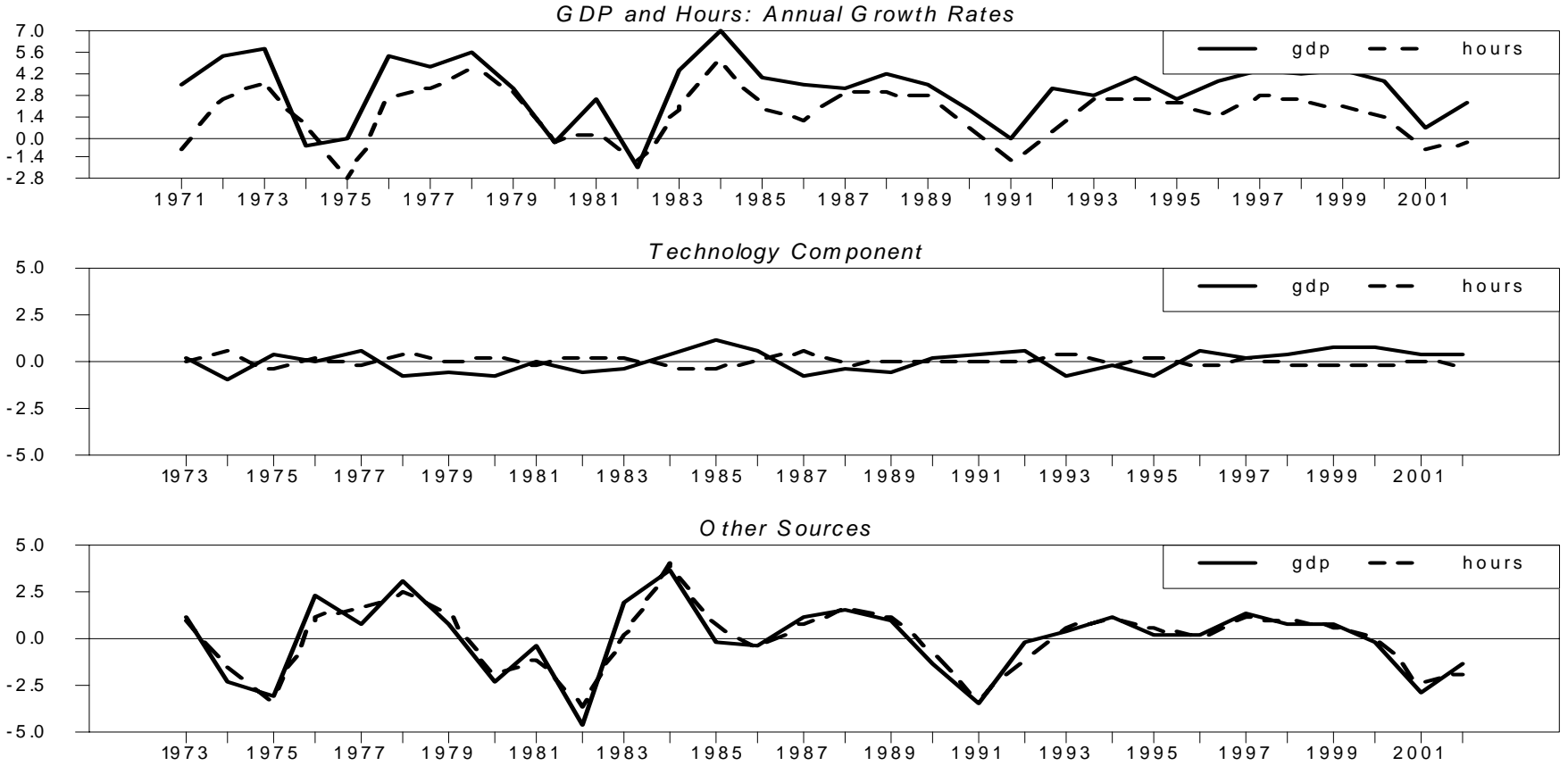

The Effects of Technology Shocks: United States

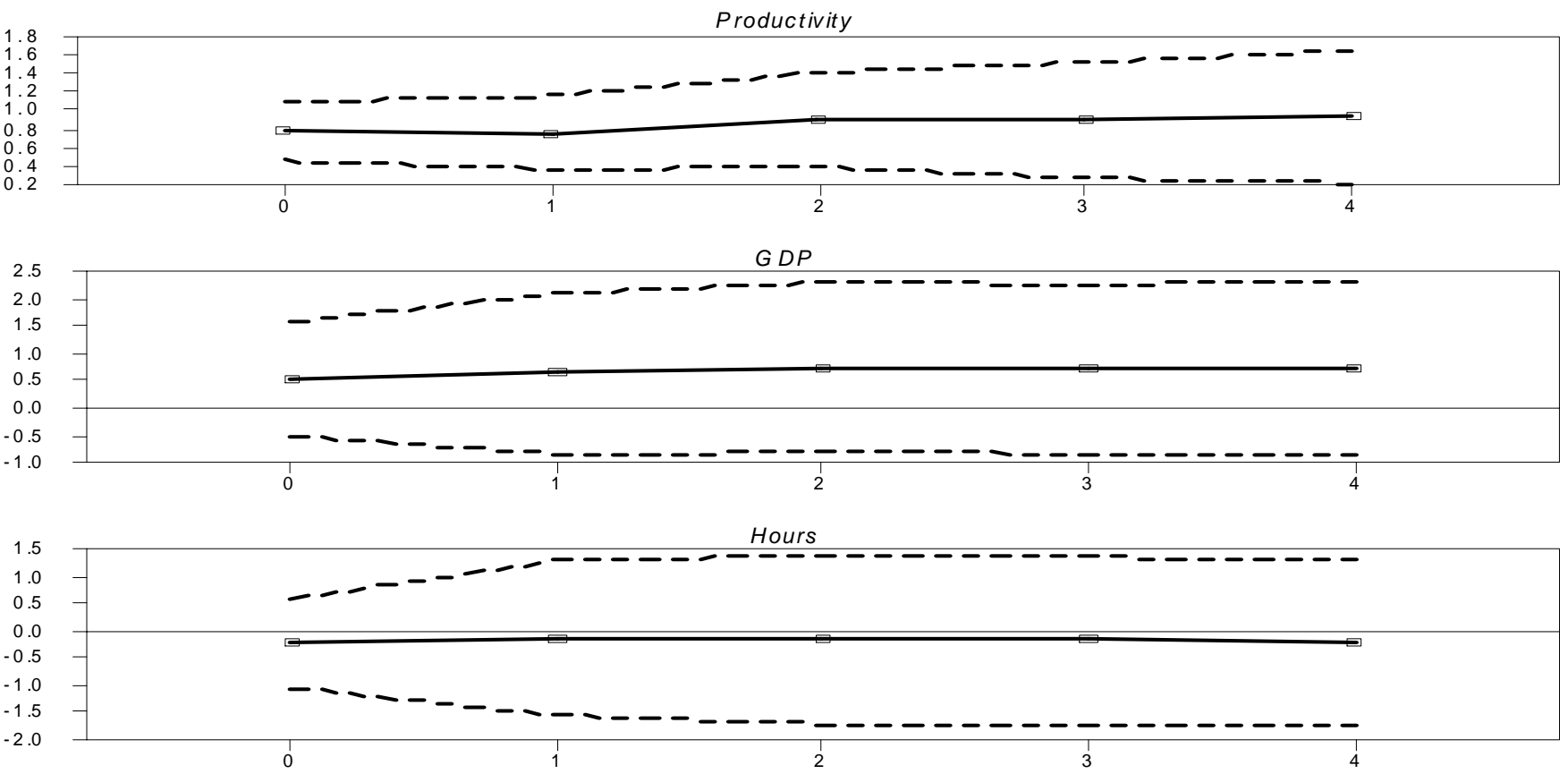




\section{FIGURE 4.B}

Fluctuations and its Sources: Canada
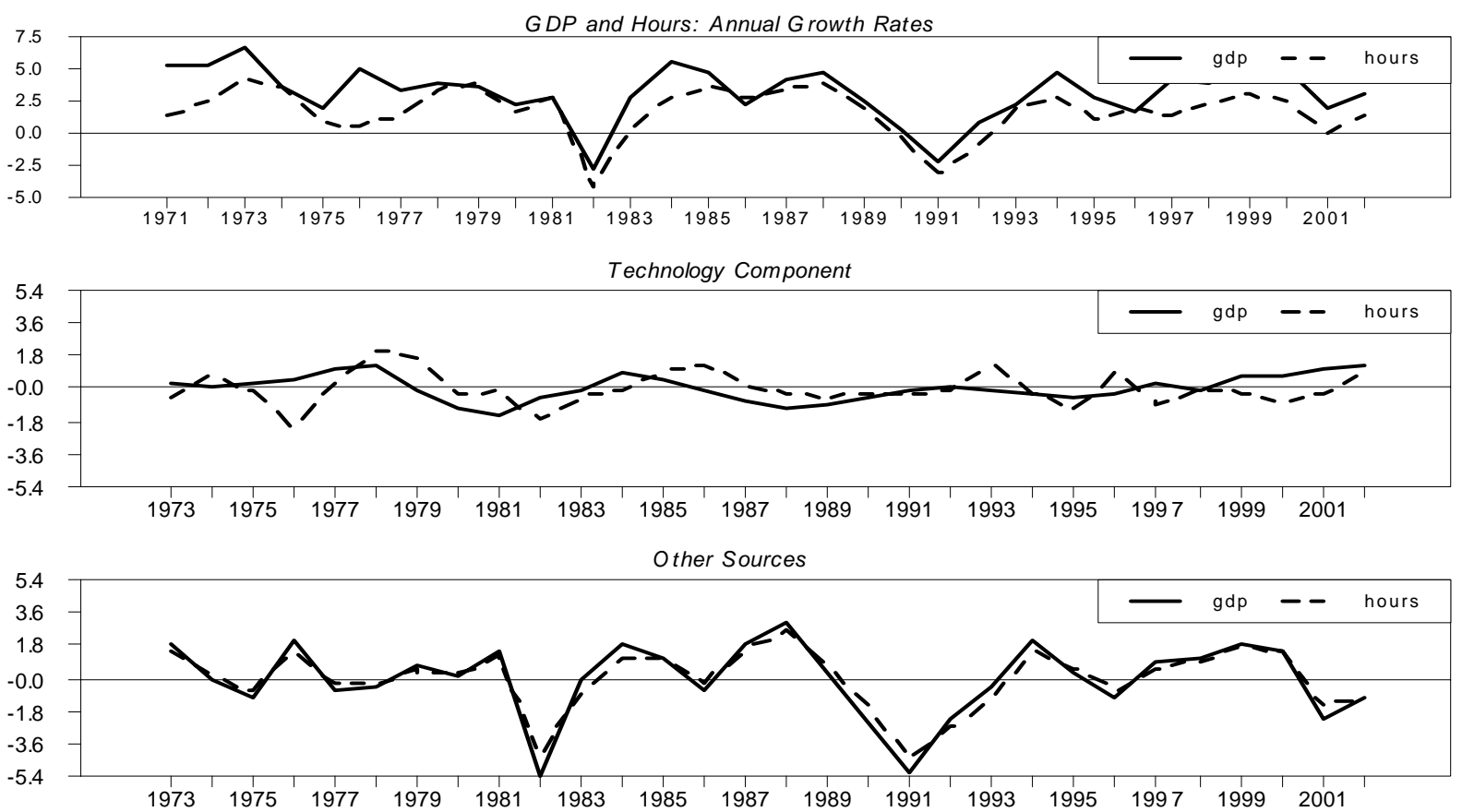

The Effects of Technology Shocks : Canada
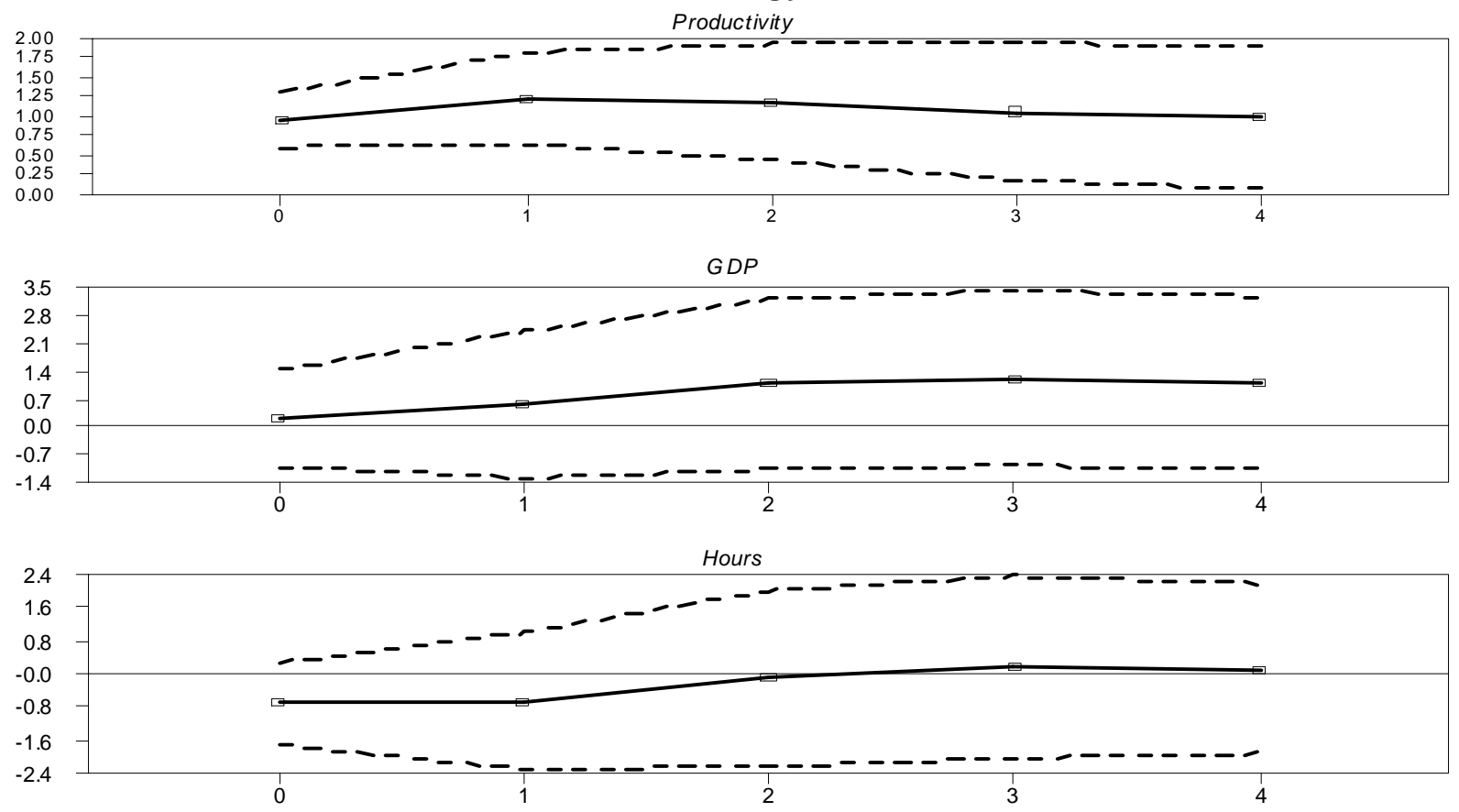


\section{FIGURE 4.C}

Fluctuations and its Sources: Japan

GDP and Hours: Annual Growth Rates
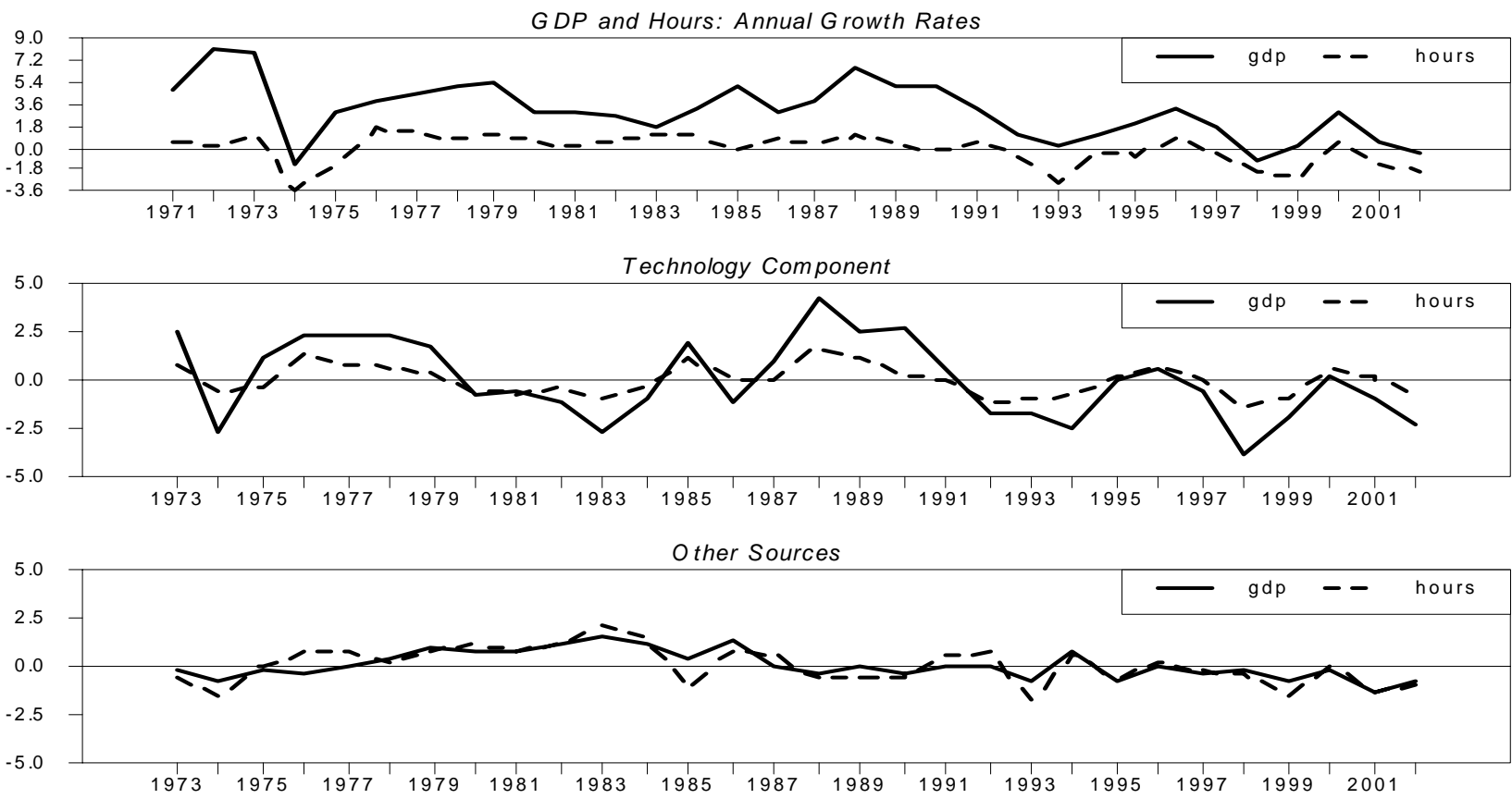

The Effects of Technology Shocks : Japan
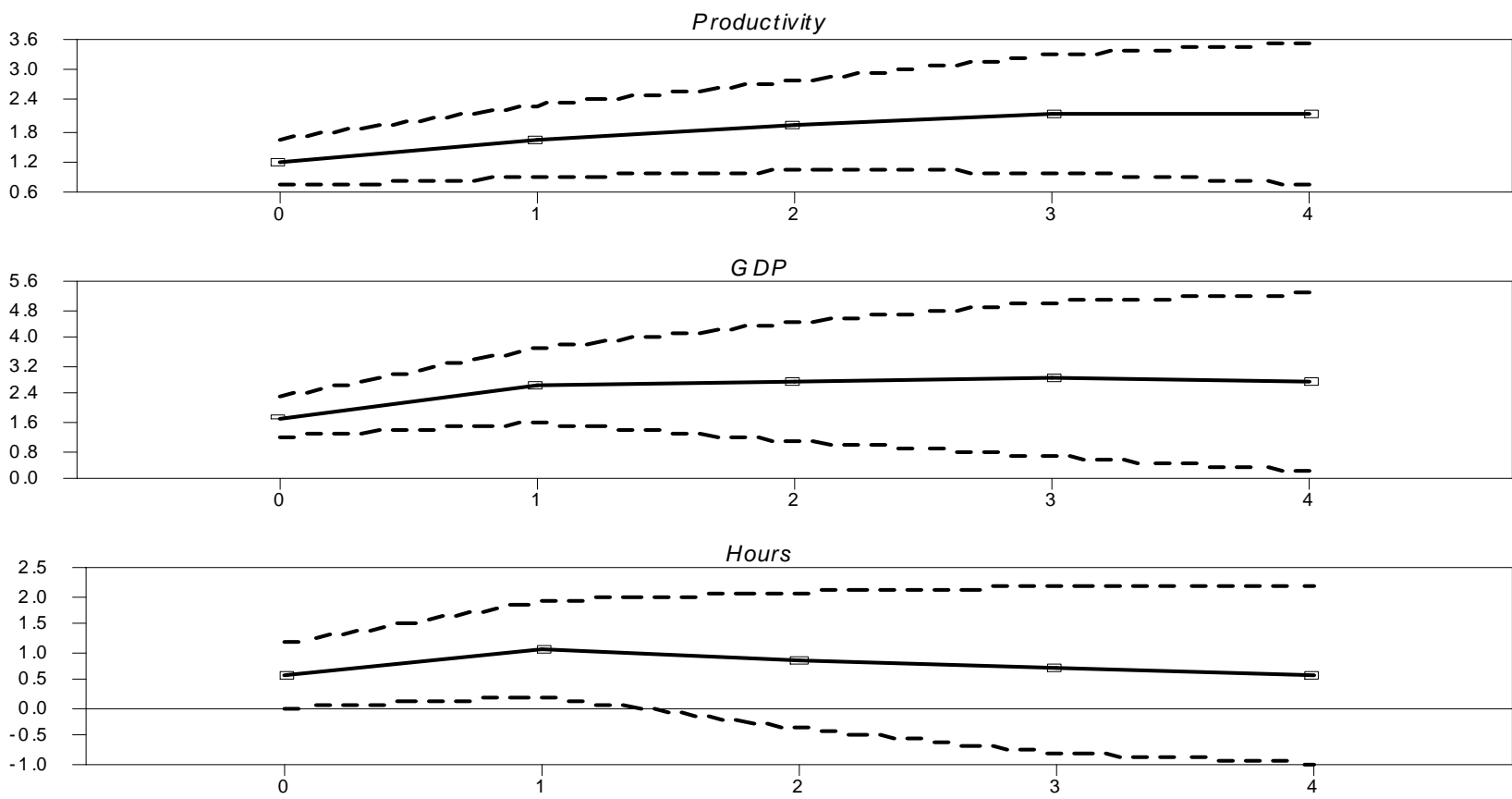


\section{FIGURE 4.D}

Fluctuations and its Sources: United Kingdom
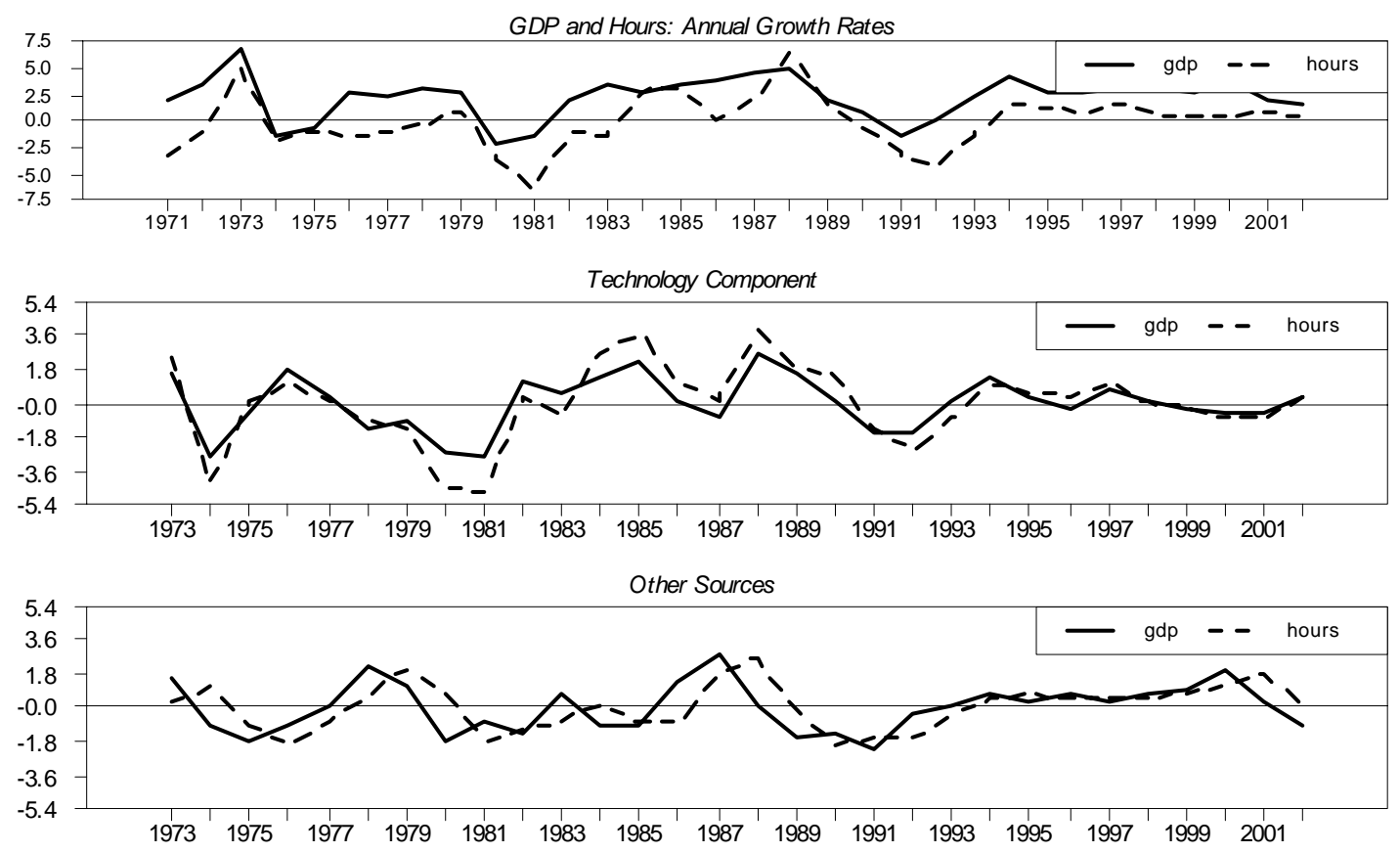

The Effects of TechnologyShocks : United Kingdom
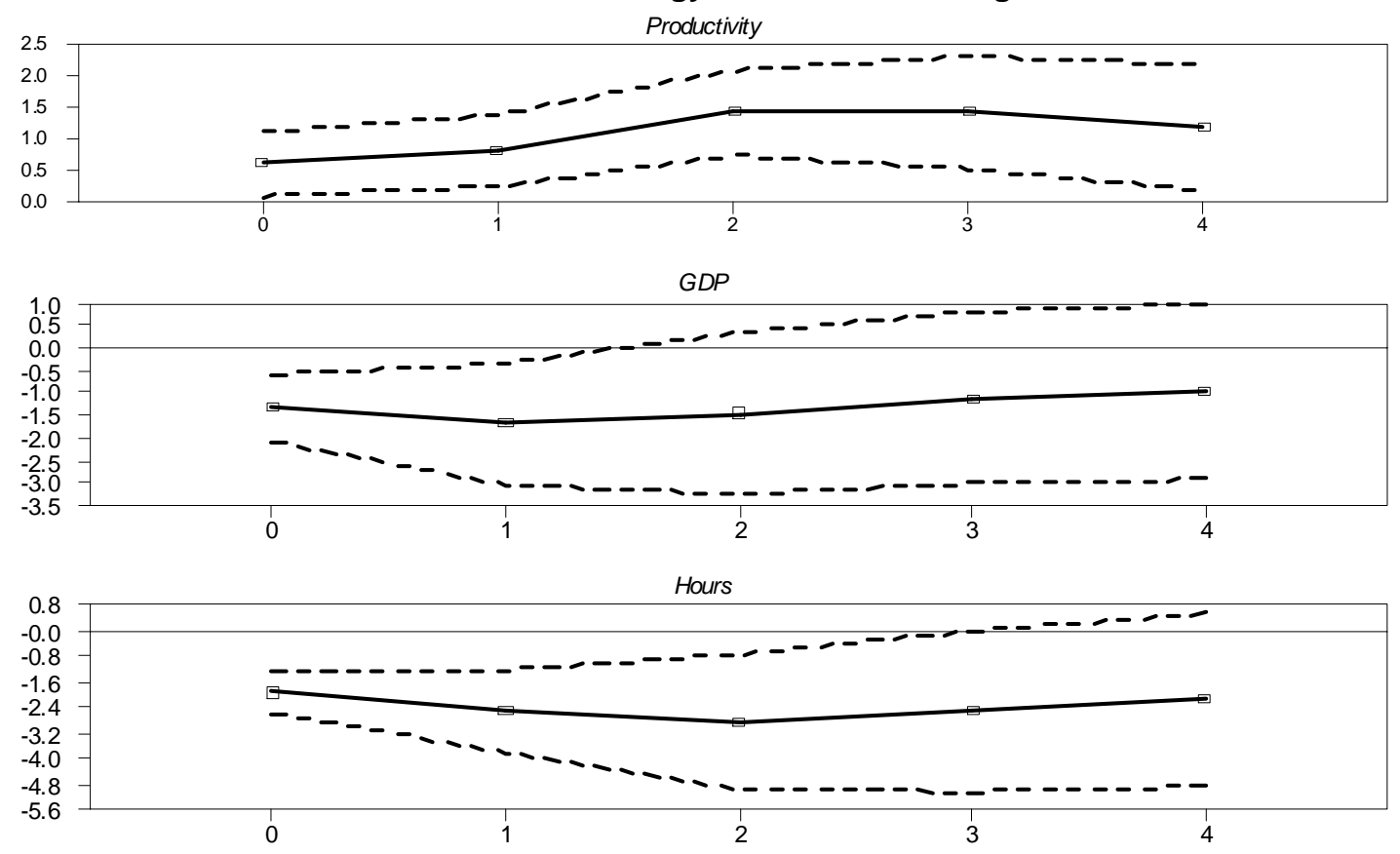


\section{FIGURE 4.E}

Fluctuations and its Sources : Germany
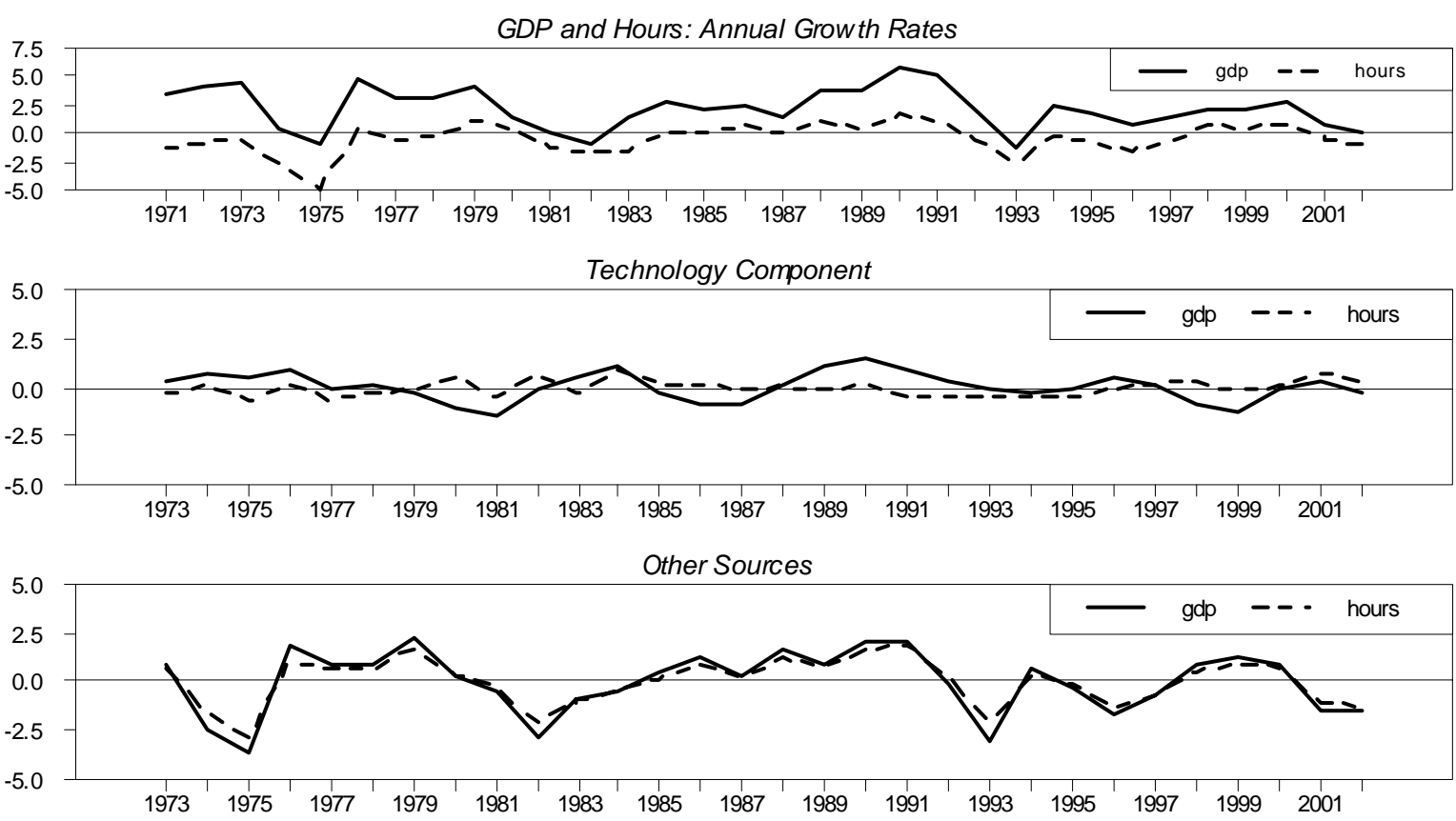

The Effects of Technology Shocks : Germany
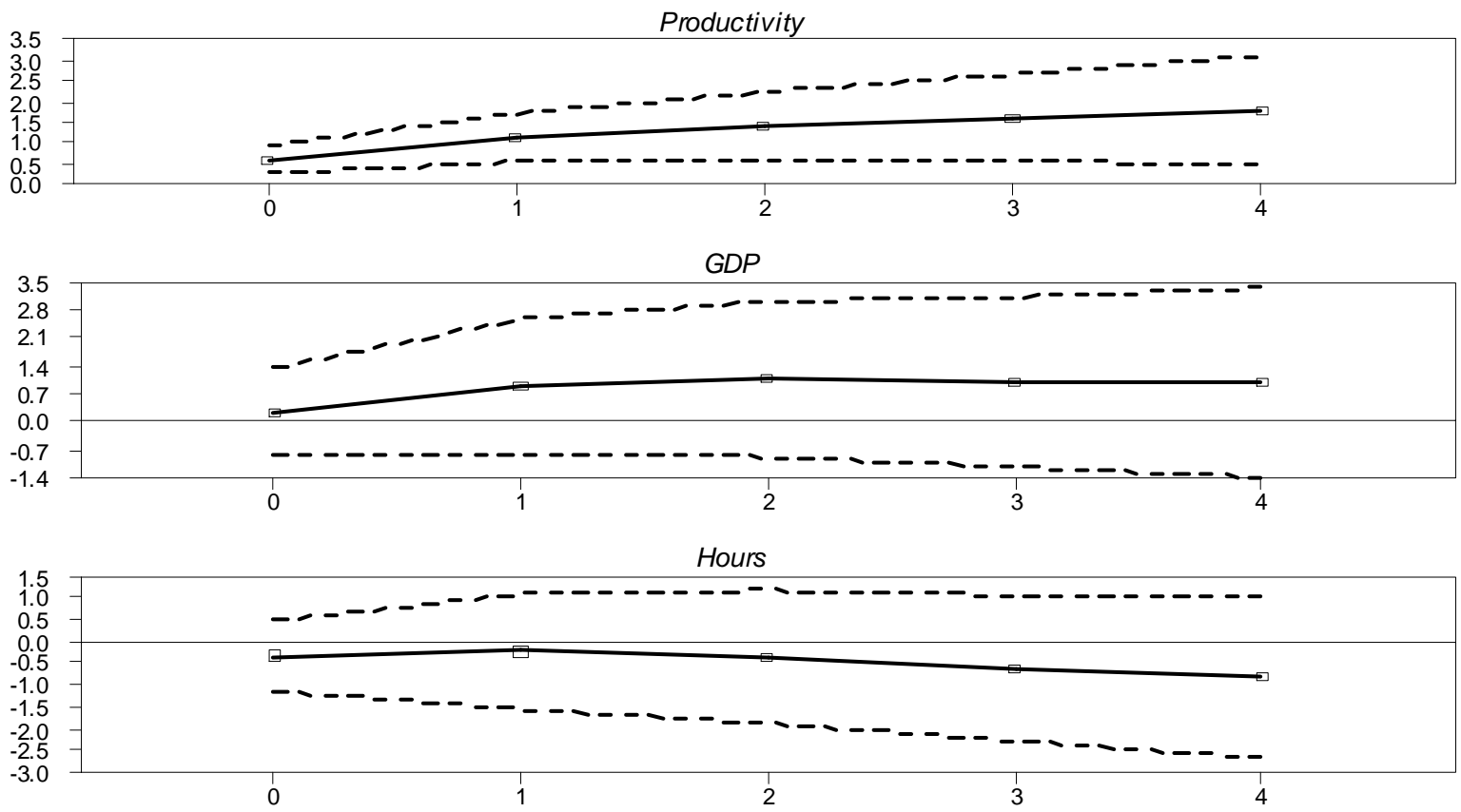


\section{FIGURE 4.F}

Fluctuations and its Sources : France

GDP and Hours: Annual Growth Rates
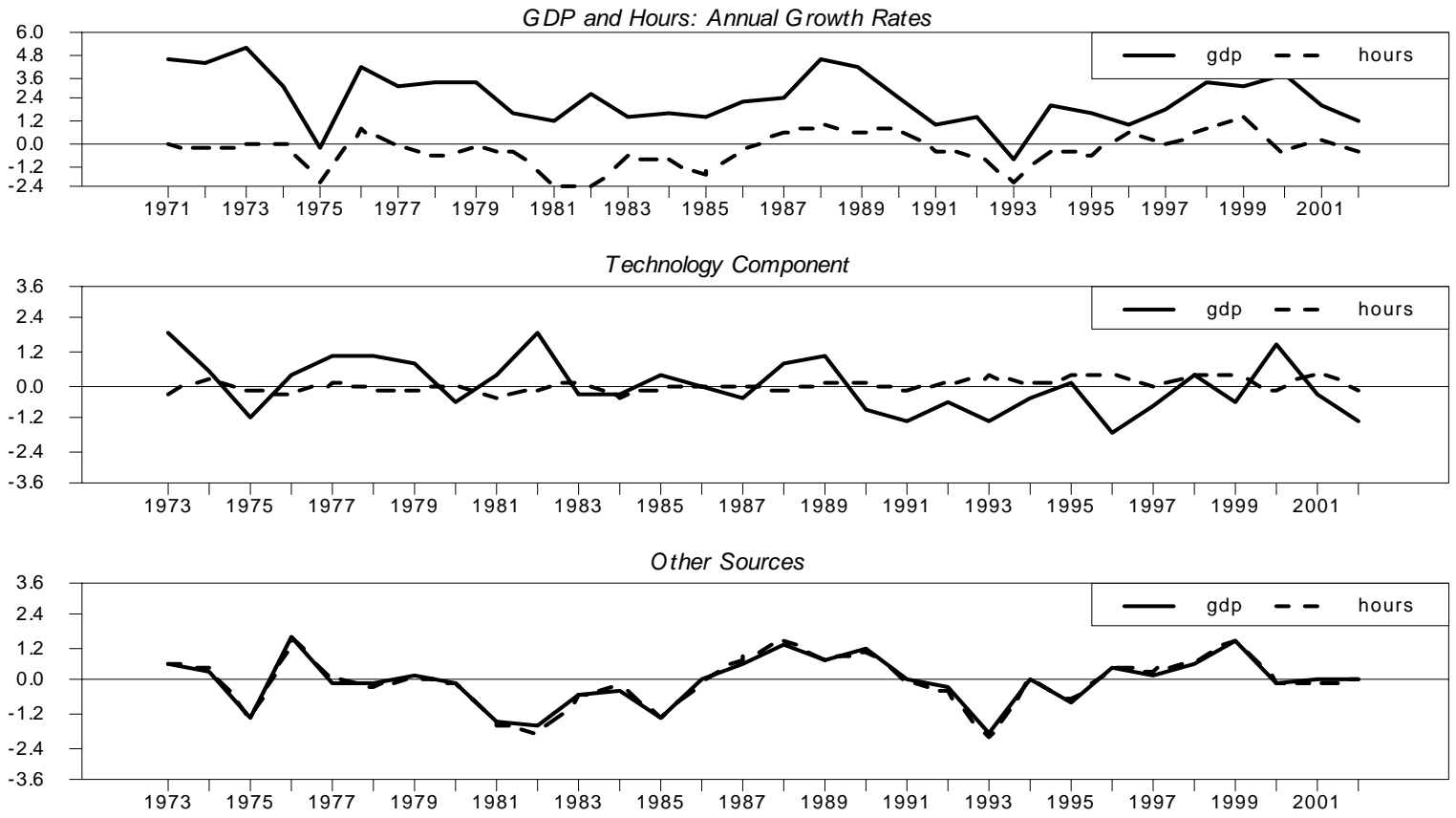

The Effects of Technology Shocks : France
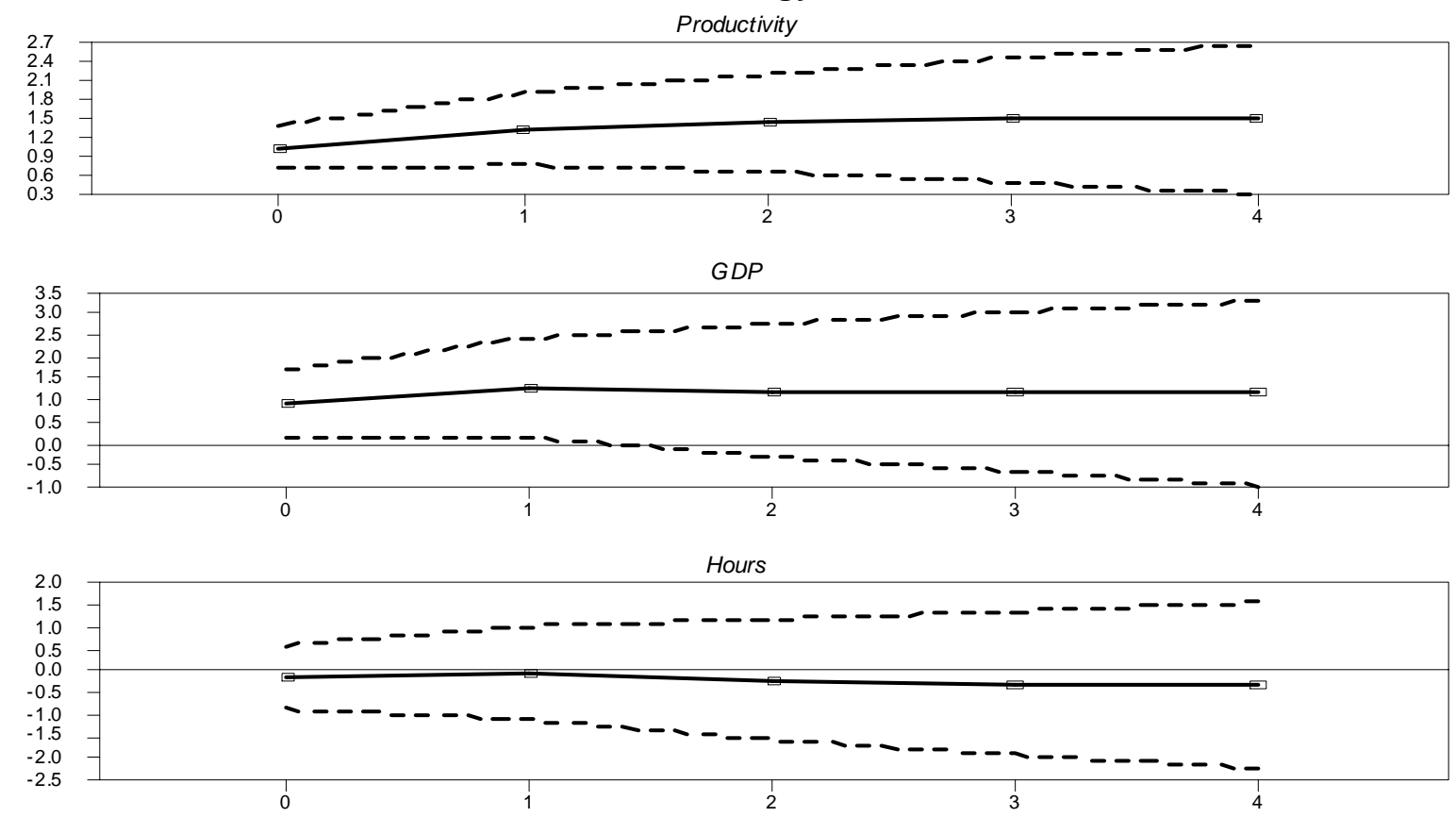


\section{FIGURE 4.G}

Fluctuations and its Sources : Italy

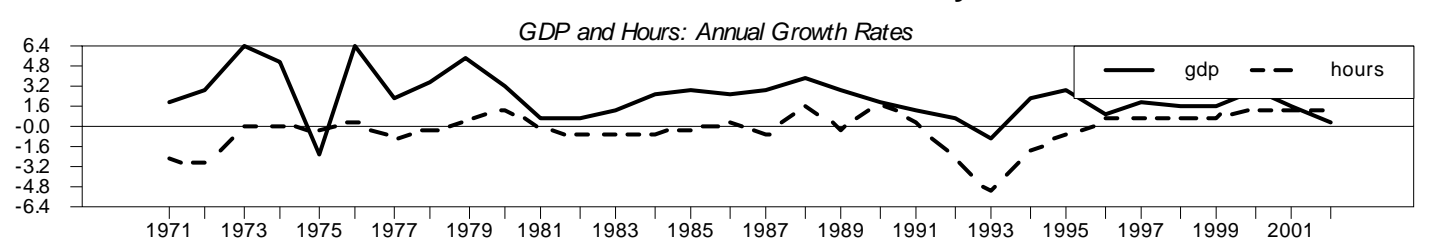

Technology Component

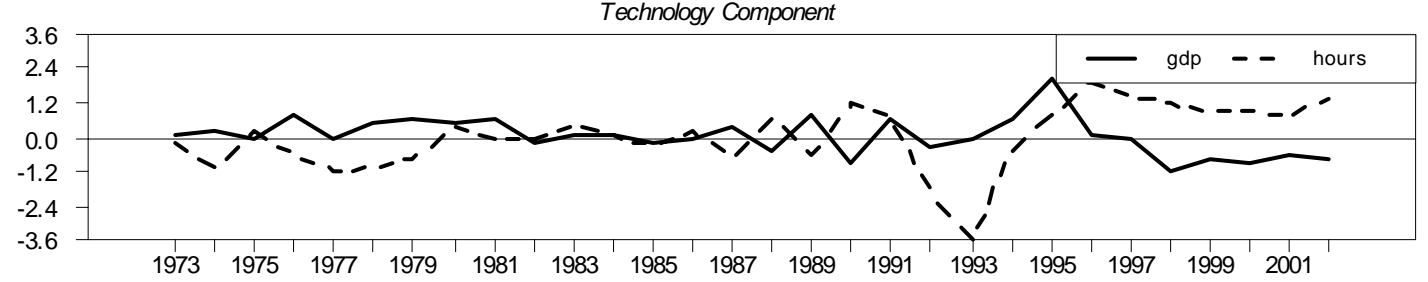

Other Sources

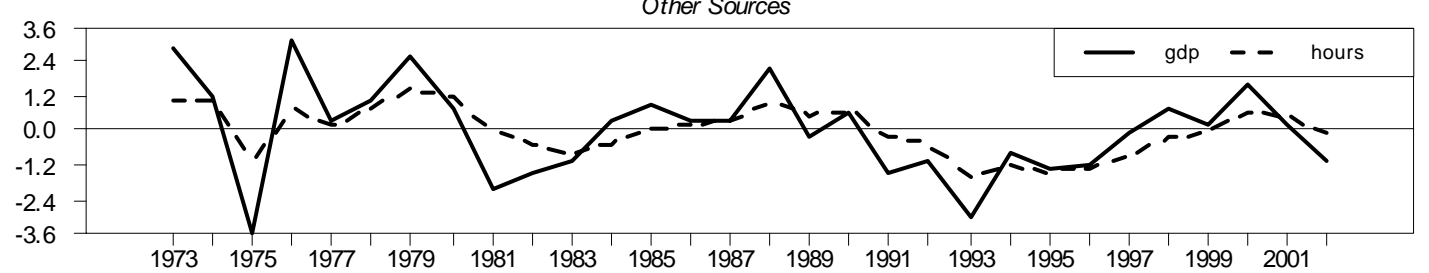

The Effects of TechnologyShocks : Italy
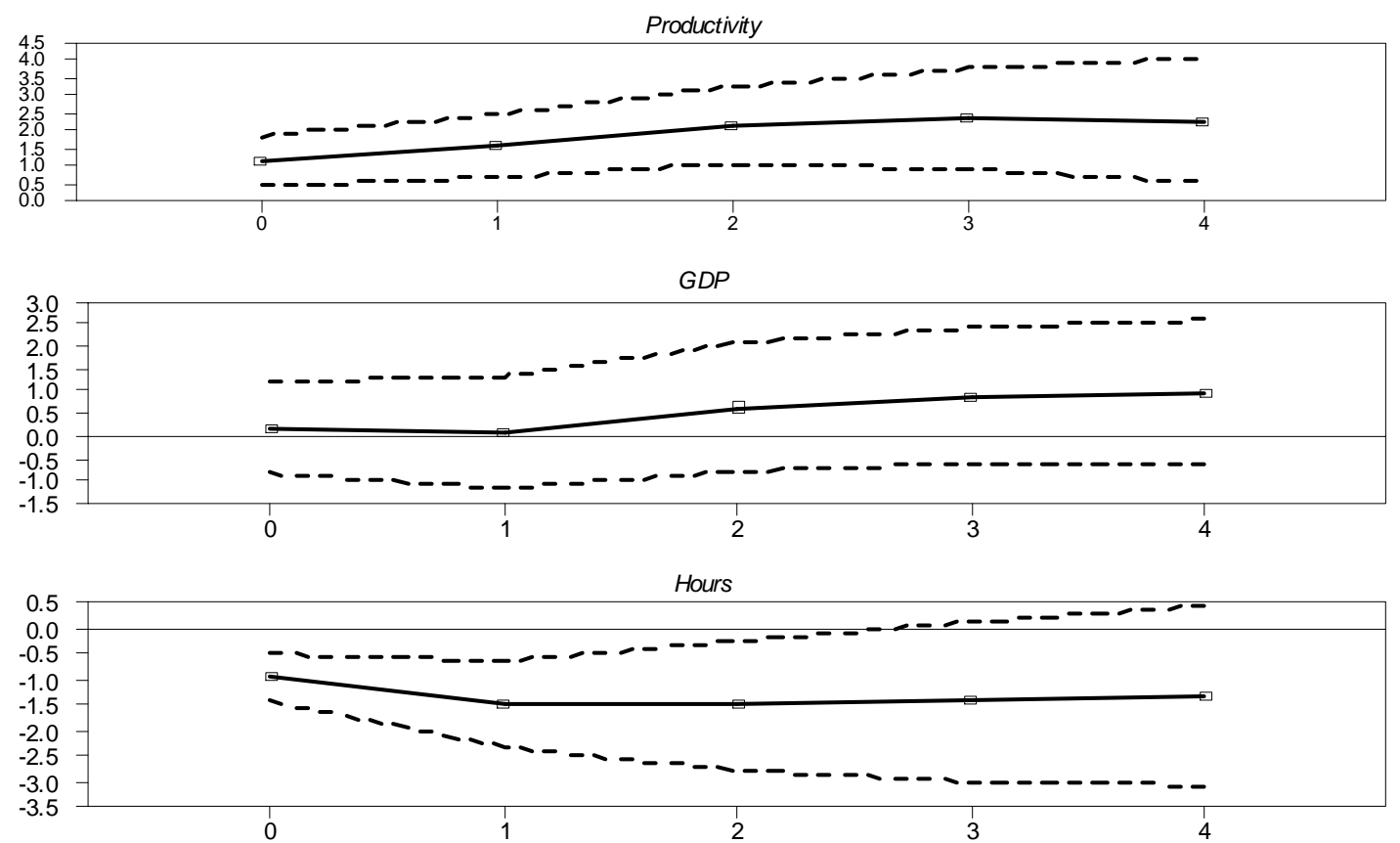